Portland State University

PDXScholar

$5-31-1977$

\title{
The vertically-oriented organization : a theoretical perspective
}

Beth M. Kurren

Portland State University

Follow this and additional works at: https://pdxscholar.library.pdx.edu/open_access_etds

Part of the Organization Development Commons, and the Social Work Commons Let us know how access to this document benefits you.

\section{Recommended Citation}

Kurren, Beth M., "The vertically-oriented organization : a theoretical perspective" (1977). Dissertations and Theses. Paper 1988.

https://doi.org/10.15760/etd.1987

This Thesis is brought to you for free and open access. It has been accepted for inclusion in Dissertations and Theses by an authorized administrator of PDXScholar. Please contact us if we can make this document more accessible: pdxscholar@pdx.edu. 
THE VERTICALLY-ORIENTED ORGANIZATION

A THEORETICAL PERSPECTIVE

by

BETH M. KURREN

A practicum submitted in partial fulfillment of the requirements for the degree of

MASTER OF SOCLAL WORK

Portland State University

1977 
TO THE OFFICE OF GRADUATE STUDIES AND RESEARCH:

Professor Gerald Frey, Ph. D. approves the

practicum of Beth M. Kurren presented May 31, 1977.

$\overline{\text { Gerald Frey, Ph.D. }}$ 
TABLE OF CONTENTS

PAGE

LIST OF TABLES $\ldots \ldots \ldots \ldots \ldots \ldots \ldots \ldots \ldots \ldots \ldots \ldots \ldots \ldots$

\section{CHAPTER}

I INTRODUCTION $\ldots \ldots \ldots \ldots \ldots \ldots \ldots \ldots \ldots$

II THEORETICAL PERSPECTIVE ON ORGANIZATIONAL BEHAVIOR $\ldots \ldots \ldots \ldots \ldots$

Organizational Concepts

III ORGANIZATIONAL CONTEXTS ......... 13

Origin and History $\ldots \ldots \ldots \ldots \ldots \ldots, 15$

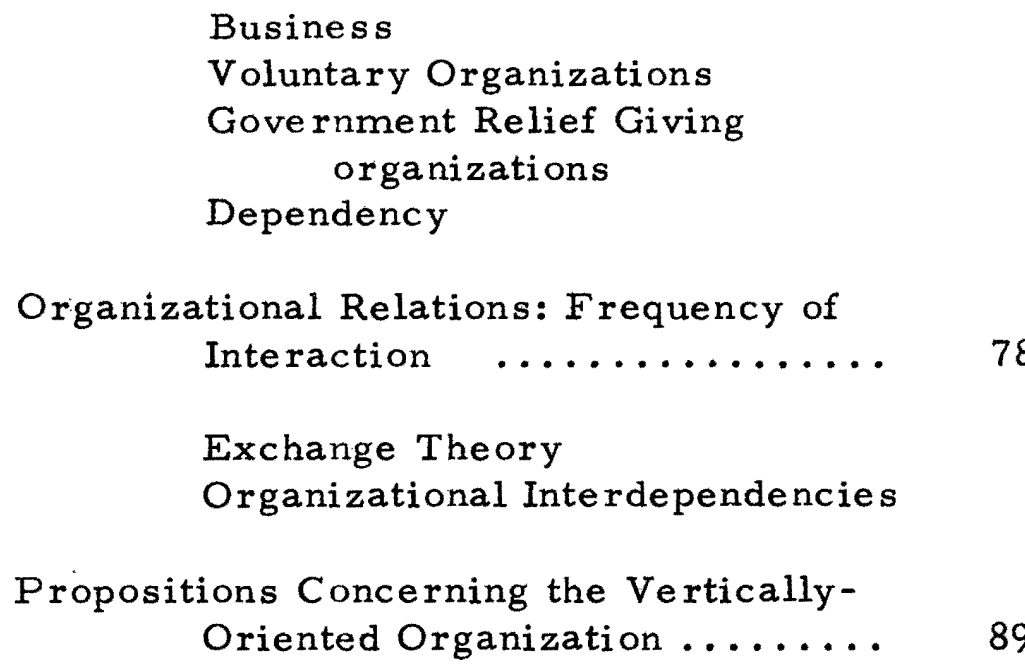

IV THE AREA AGENCY ON AGING: CASE MATERIAL $\ldots \ldots \ldots \ldots \ldots \ldots \ldots \ldots, 92$ 
Direction and Source of Authority....

Control of Resources ..........

Anticipating Behavior of the Area

Agency on Aging .........

Compliance

Control of Dependency

Legitimation of Goals

Interactions

Coordination 


\section{LIST OF TABLES}

TABLE

PAGE

I A Summary of Exchange and Power ......... 66

II Organizational Perceptions Concerning the

Impact of the Area Agency on Aging on the

Service Community .................... 106

III Organizational Perceptions Concerning the

Impact of the Area Agency on Aging on the

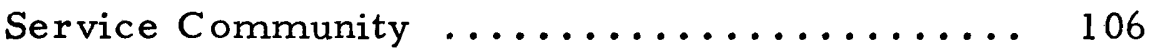

IV Frequency of Collaborations of Organizations

to the Area Agency on Aging ........... 108

V Frequency of Intense Contacts of Organizations

to the Area Agency on Aging ............. 109 


\section{CHAPTER I}

\section{INTRODUCTION}

Several theorists in the area of interorganizational analysis focused on the distinction between the "vertically-oriented"organization (where the authority runs downward from the federal or state to local level, and where the vast bulk of resources are controlled by a parent agency), and the "horizontally-oriented" organization (where the authority runs horizontally among a particular network of organizations). The intent of their inquiry has been to illustrate the problems associated with the vertically-oriented organization in terms of service delivery within a particular network of organizations. For instance, Burton Gummer, in his study of the interorganizational relationships of a public welfare agency, found that vertically-oriented organizations would have little involvement with other organizations in its functional and geographic environment because of its dependence upon a parent body for the supply of virtually all of its resources (Gummer, 1974). Because the vertically-oriented organization is dependent upon the parent agency for its survival, it will be more concerned with internal affairs, and thus less concerned with interorganizational activities. 
Sol Levine and Paul White, in their study of community health organizations, concluded that local member units of verticallyoriented organizations, because they are less dependent upon the health system, and can obtain resources outside the system, interact less with other local organizations than horizontally-oriented organizations (Levine and White, 1961). This study also pointed out that this independence from the rest of the local health system and greater dependence upon a system outside the community causes specific types of disagreement among the local system.

Finally, Levine, White, and Paul in their study of 68 voluntary health care agencies in four communities, point out that vertically-oriented organizations with local chapters or affiliates are limited or circumscribed by priorities established by national bodies. By contrast, organizations such as the Community Chest and the United Fund (both horizontally-oriented organizations) are geared to the local community. Given the diverse sources of authority it is understandable that maximal inter-agency cooperation is not always attained (Levine, White, and Paul, 1963).

All of these studies have documented a structural explanation of the cause of interorganizational coordination. Namely, the organizations' capacity to engage in interorganizational activities will be a function of its location vis-a-vis its major providers of resources. Those organizations located in a vertically-oriented, corporate 
structure will tend to interact less with other organizations in a particular functional or geographic community causing a serious problem of fragmentation in the delivery of services.

Given this perspective, the current trend in domestic national policy toward decentralization of policy-setting and decision-making to local levels of government (the "new federalism") can be expected to worsen the already high degree of fragmentaion in service delivery systems. The traditional approach to program integration in the past has been the guidelines surrounding the granting of federal funds to the states and localities. These guidelines have always placed a high priority on program coordination and integration as a condition for the receipt of funds. The "new federalism," despite its attempt to support the devolution of power to state and local governments, has also placed a high priority on integration and coordination as a condition for the receipt of federal dollars. To the extent that the "new federalism" pursues a strategy of "no strings" attched funds, then one can expect the kind of internally-oriented behavior that characterizes the vertically-oriented organization to persist.

This study will focus on a particular program (The Area Agency on Aging) which was developed in response to the problems of fragmentation among the service delivery system for the aging. In so doing, two very important questions will be answered:

1. To what extent does the characteristics of the Area Agency on 
Aging resemble a vertically-oriented organization? 2. To what extent does the Area Agency on Aging gear its activities toward the coordination of services for the elderly? The basic assumption is that because the Area Agency on Aging resembles another vertically-oriented organization, its main focus of attention will be on internal concerns (i.e., survival) rather than interorganizational activities. 


\section{CHAPTER II}

\section{THEORETICAL PERSPECTIVE ON ORGANIZATIONAL BEHAVIOR}

The model used in this description of vertical and horizontal organizations is an open systems perspective which focuses on a network of organizations in interaction with its environment. As Howard Aldrich (1973) has pointed out, the major difference between this approach and more traditional approaches to organizational analysis is that, 1) it places a greater concern on factors making for internal or intraorganizational conflict and variation as opposed to an emphasis on internal cooperation and stability, and 2) it emphasizes turnover and conflict within a network of organizations rather than studying a particular unit-set. ${ }^{1}$ This approach illustrates the difference between interorganizational analysis and organizational analysis in that it starts out with the assumption that conflict is a given, and the elimination of this conflict is a deviant instance and likely to lead to a disruption of interorganizational relations (Litwak

${ }^{1}$ A network has been defined as "... consisting of all the groups and organizations as well as the consumers associated with a particular production system designed to service some customer or client." (Hage, 1975: p. 212) 
and Hylton, 1972). It stresses the operation of social behavior under conditions of partial conflict and the factors which are equally derived from all units of the interaction rather than being differentially weighed by authority structure.

By stressing the fact that the environment makes conflicting demands on the organization, internal variation becomes essential if organizations are to respond to environmental changes. Many available contributers to a theory of organizational structure do not incorporate the direct source of variation in formal structural arrangements, i.e., the strategic decision of those who have the power of structural initiation. A theoretical incorporation of the decision-making process within a particular organization has suggested that,

$$
\begin{aligned}
& \text {... constraints upon structural choice are } \\
& \text { weakened in their effect to the extent that } \\
& \text { the decision-maker perceive that the design } \\
& \text { of the organization's structure only has a } \\
& \text { limited effect on performance levels } \\
& \text { achieved. (Child, 1972) }
\end{aligned}
$$

This is due in part to the contextual constraints facing the organization. Despite the fact that they perceive structural design to have some impact upon performance levels, the dominant coalition (or organizational decision-makers) within the organization may be in a position to institute modifications to the context in order to maintain a preferred structure without harm to the performance level. 
However, if the organizational decision-makers perceive the structure as posing certain performance implications they may prefer to "satisfice": to trade-off some potential gain in performance for a congenially structured mode of operation (Child, 1972). Consequently, they may have some choice over performance standards. In the open-systems model, the exercise of strategic choice can be defined as "the determination of basic long-term goals and objectives of an enterprise, the adoption of a course of action, and the allocation of resources necessary for carrying out these goals" (Chandler, 1962: p. 13). It is important to note here that the decision-makers prior ideology will color this evaluation to some degree. Structure, in turn, can be defined as "the design of the organization through which the organization is administered" (Chandler, 1962: p. 14). As Alfred Chandler (1962) has shown in his study of four major corporations in the United States, "structure follows strategy, and that complex types of structure is the result of the concatenation of several basic strategies"' (Chandler, 1962: p.14). Those aspects of the organization's variability which approximately map the environment are selectively reinforced through internal and external mechanisms. In terms of internal mechanisms, strategic action will involve an attempt to establish a configuration of manpower, technology, and structural arrangements which is internally consistent and consistent with the size and nature of the operations 
planned (Child, 1972). Internal mechanisms can either be formalized through a planning process or kept informal through boundary personnel. Strategic action with regard to external variables may include a move into or out of a given market or areas of activity in order to secure a favorable demand or response that will be expressed by a high valuation of the organization's product or services. Through the reinforcement of organizational activities, external mechanisms are performed (Aldrich, 1973). The conjunction of efficiency (internal) and demand (external) will in the end determine the organization's overall level of performance.

\section{Organizational Concepts}

Organizations in this study will be treated as goal-directed, boundary maintaining, information processing activity systems. Within each organization, abstract purposes, charter goals, and the like come to be translated into ongoing programs (Benson, 1975). Once this process has been reached and advanced, the decisionmakers within their perspective organizations are responsible for expanding their established programs. Abstract goals then recede into the background of shared assumptions which are taken for granted and may be employed for the legitimation of ongoing programs (Benson, 1975). Other key concepts in this approach include the idea of task environment, domain, and organizational sub-systems. 
Task Environment. James Thompson (1976) has described the task environment as "those parts of the environment which are relevant or partially relevant to the goal setting, goal attainment, survival or effectiveness of the organization" Richard Hall (1972). makes a distinction between the general environment (i.e., political technological, ecological demographic, and cultural) and the specific environment (or task environment) which he describes as being composed of the organizations and individuals with which the organization is in direct interaction. This raises a question with regard to the study of interorganizational relations, i.e., to what extent need the theorist demonstrate a clear link between something in the organization's environment and change in the organization's behavior. The definition of the task environment which this perspective takes is defined as "... consisting of all parts of the environment potentially or actually relevant to the organization's behavior" (Aldrich, 1973: p. 51). This takes into consideration the organization's behavior despite its awareness of all parts of the environment.

Domain. The domain of the organization is defined as the subset of the task environment and refers to a range of activities claimed by the organization itself. The possession of a domain permits the organization to operate within a specific sphere, claiming support 
for its activities and defining proper practices within its realm (Benson, 1975: p. 232).

The in-put domain consists of those points at which the organization is dependent upon inputs from the environment, and can be broken down into two dimensions. One is the range of products or services needed and the technology to obtain them, and the other is what Roland Warren (1973) defines as the in-put constituency which consist of,

$$
\begin{aligned}
& \text {.. those organizations or actors acknowledged } \\
& \text { by the organization as supporting, financing, } \\
& \text { promoting, providing program material, or } \\
& \text { making decisions regarding the functioning of } \\
& \text { the organization. (Roland Warren, 1973: pp. } \\
& \text { 173-174) }
\end{aligned}
$$

The out-put domain consists of those points at which the organization is dependent upon exchanging its products or services for resources from the environment. The out-put constituency consists of those other organizations acknowledged by the organization as being an appropriate target for its activities. Finally, the through-put domain consists of the points to where the organization is dependent upon its environment for processing its services (Aldrich, 1973).

Resources. In focusing on relationships between organizations, it is important to determine the elements that flow between organizations and their environment or other organizations. These elements will be defined in terms of resources sought after by the organization 
or the units that possess those resources. Following Yuchtman and Seashore (1967), it is assumed that organizational decision-makers are typically oriented to the acquisition and defense of an adequate supply of resources, and that this orientation determines within fairly restrictive limits, the nature of interactions both on the service delivery level and in the performance of mandated functions.

Two types of resources are paramount to this perspective: money and authority. Money is of obvious importance to the maintenance and the expansion of programs, the recruitment of personnel, and the purchase of buildings and material. Authority refers to the legitimation of activities, the rights and responsibility to carry out programs of a certain kind dealing with a broad problem area of focus (Benson, 1975: p. 232).

The assertion that organizations pursue an adequate supply of money and authority leaves a number of questions unanswered. Many different actions may be compatible with this broad and general requirement. J. Kenneth Benson (1975) has addressed this issue by the elaboration of operational decision criteria governing interagency relations. The following are a list of such decision rules: The first is the fulfillment of program requirements. The organization's claim to an adequate supply of resources (money and authority) will be based on the adequacy and efficiency of established programs. Thus, agencies will be reluctant to undertake tasks or tolerate practices of 
other organizations that interfere with the fulfillment of present programs. Second is the maintenance of a clear domain of high social importance. This criteria is based on the as sumption that organizations strive for autonomy. Decision-makers are oriented to a clear-cut, uncluttered claim that includes a set of important activities. Finally, the third is the extended application and defense of an agency's paradigm, i.e., agencies are committed to their own definitions of problems. According to Benson, (1975) organizations taking other approaches constitute an implicit threat to the flow of authority and money into an organization. 


\section{CHAPTER III}

\section{ORGANIZATIONAL CONTEXTS}

Many organizational theorists have focused to a considerable degree on the impact that certain contextual factors (factors such as origin and history, dependency, interorganizational relations, etc.) have on the structure and performance level of an organization. Pugh, et al, (1969) in their study of several British industrial firms, found that certain contextual factors had a direct bearing on the structure of an organization. For example, they found that older organizations tend to be more decentralized. Furthermore, Blau and Schoenherr (1971), in their study of employment agencies throughout the country, found that the size of an organization had a tremendous amount of correlation with certain structural variables. Both of these perspectives, however, are based more on a closed system perspective. They do not take into consideration the process of strategic choice or internal variation among organizations. The following section will describe corporate (vertically oriented) as well as federate (horizontally oriented) organizations in terms of how they have responded to and/or adapted to certain contextual variables. In so doing, some of the distinguishing features between 
vertical and horizontal-types of organizations will be illustrated.

\section{ORIGIN AND HISTORY}

In looking at the history of organizations, the major focus will not be on origins per se, but on the consequences for organizational growth and expansion, such as the capacities of the organization to carry out the purposes for which it was established. This section, therefore, will focus on the consequences which led to the development of three distinct kinds of organizations: large scale business organizations, voluntary organizations, and government controlled relief-giving organizations. As will become evident, there are many similarities between these organizations with regard to the kinds of environmental and technological constraints facing them which served to influence the kinds of decisions that were open to the organizational decision-maker. What is of particular interest to this study, however, are the variations between these organizations in terms of how they responded to these constraints. These variations help to further clarify the difference between the verticallyoriented and the horizontally-oriented organization with regard to their impact on the organizations' level of efficiency and performance.

\section{Business Organizations}

Alfred D. Chandler (1962), in his book Strategy and Structure, 
mapped out a sort of administrative history of "industrial enterprise" (large private, profit oriented firms involved in handling goods in some or all of successive industrial processes) using the rationale of "strategic choice." The overall thesis of his investigation illustrated the fact that changes in organizational structure was related to ways that the enterprise expanded, and that re-organization of the organization were influenced by the state of administrative art in the United States, i.e., strategic growth resulted from an awareness of opportunities and needs - created by changing populations, income, and technology - to employ existing or expanding resources more profitably (Chandler, 1962: p. 73). Consequently, by looking at the ways that these enterprises expanded it will be possible to understand more fully the origin and history of private, profit-making vertically as well as horizontally-oriented organizations.

Early American Enterprises. Before 1850 very few American businesses required a full-time administrator or a clearly defined administrative structure. Industrial enterprises were quite small and generally were family-run and operated. Those responsible for the operation handled all the basic activities - economic, adminis trative, operational, entrapaneurial, etc. In the agrarian and commercial economy of ante-bellum America, business administration as a distinct activity did not exist. In mining, manufacturing 
and transportation, the general superintendent was in charge of supervision of the labor force while in larger textile manufacturing industries, the president or treasurer was in charge of finances and arranged for the purchasing of activities (Chandler, 1962).

Yet before the $1850 \mathrm{~s}$ a few of the largest economic enterprises in the U.S. did develop distinct administrative structures.

John Jacobs Astor's American Fur Company, Nicholas Biddle's Second Bank of the United States, or rather boards of directors of private corporations that built the major canals and first railroads and the state board of public works, all these had field units and a headquarters. (Chandler, 1962: p. 15)

For instance, Astor's American Fur Company managed its monopoly of the fur trading industry in the vast region west of the Mississippi. The department headquarters managed its out-fits each headed by a trader Besides this supervision, they did most of the marketing for supplies. Although these were some of the largest enterprises of their day, the Bank and Fur Company had little impact on the later development of administrative organization in the large industrial firms in this country - the Fur Company was virtually dissolved when Astor withdrew from the partnership.

This distinct administrative structure was particularly significant in the construction of the Erie Canal and other transportation works during the 1820 s and 1830 s. During the construction, 
the line of the canal was divided into a number of divisions, each in charge of an assistant engineer who was responsible for surveying the route and then inspecting the progress of the construction. At the headquarters a chief engineer supervised the works of the assistants in the field (Chandler, 1962). Thus, there was a clear distinction between the administrative component (a major headquarters) and an operational component (the field unit). However, the task of the organization was more technical than administrative, it was only to lay out the line and then see that the contractors carried out plans. A board provided the funds and made the major decisions as to the location. Until the 1850 s the contracting firms which actually built the transportation works remained small and had little need for systematic organizational structure since such a contractor rarely built more than one section of a road at a time (Chandler, 1962). He could, therefore, supervise the job himself.

Expansion of Industrial Enterprise. With the completion of the great east-west trunk lines early in the $1850 \mathrm{~s}$, administration became a full-time task in American business. The largest enterprises in the nation required new methods of management. They needed to set up a system where there was a detailed definition of the lines of authority and communication between headquarters and the many divisions. This required a constant flow of reports and 
superintendents who would be responsible for coordinating, appraising, and planning the work of the operating divisions.

As the roads grew in mileage, and the volume of traffic expanded, the number of their administrative personnel increased and their operating structure had to be re-defined (Chandler, 1962). They spelled out the lines of communication and authority between the major and anscilliary units within the transportation department and also between the transportation and other major departments such as traffic and accounting. This growth and expansion in the railroads helped to enlarge the market for American manufacturing, mining, and marketing firms. The railroads permitted and often required that these enterprises expand and subdivide their activities, thus calling for specialization and the encouraged use of more complex machinery. This spurred further increases in out-put and so provided another pressure for expansion and continued growth. In addition to the expansion of the railroad, other environmental factors helped to influence the growth of major industrial enterprises in the United States. Between 1840 and 1880 , the urban population grew from $11 \%$ of the total population in the U.S. to $28 \%$, or $4 \%$ per decade. In 1800 , the rural population stood at 36 million and the urban population equaled 14.1 million. By 1900 , the figures were 45 million (rural) and 30.2 million (urban), and by then agricultural income was estimated at only 3,034 million out of a total 
national private production income of 14,000 million dollars (Chandler, 1962: p. 23).

In meeting the needs posed by the environmental factors, many American factories, mining and marketing firms began to expand their domains through vertical integration by multiplying the volume of out-put and later these enterprises very quickly expanded through geographic dispersion - they started to buy or build other units distant from their original locations. As James Thompson (1967) has pointed out, in integrating forward an organization acquires distribution capacity greater than its out-put. This requires that the organization increase its out-put, which the task environment may not be able to handle. A strategy for organizations to take when capacity is in excess of what the task environment can support will be to expand their domain by increasing the population served. In other words, they expand through geographic dispersion (Thompson, 1967). These strategies of vertical integration and geographic dispersion had their beginnings before the depression of the 1870s. Only afterwards, in the 1880 s and 1890 s did the great impersonal corporate enterprises appear in any numbers in American industry.

The Growth of Corporations. The large multi-function enterprise sprang from two quite different strategies of growth and expansion. In one strategy a single company began to expand and 
integrate by creating its own marketing organization. In another, a number of manufacturing companies which had joined together in a horizontal combination such as a trade association, pool, trust, or holding company - consolidated their manufacturing activities and then moved quickly forward into marketing or backwards into purchasing (Chandler, 1962). This later type was employed by organizations producing more staple commodities by an older, less complex technology. Both strategies, in turn, were in response to a rapidly growing market due to population growth and the expansion of the railroad making more accessible certain manufactured goods. The more common road to the formation of the vertically integrated industry was by way of "horizontal combination" (the combination of several diverse manufacturing industries) and consolidation (Chandler, 1962).

The threat of excess capacity appears to have been the primary reason to the initial combinations in most American industries. The reason for this being that the rapid increase in out-put of small enterprises exceeded immediate demand. The market was gutted. Consequently, these organizations combined in order to control or limit competition by setting price and production schedules.

However, as Chandler (1962) pointed out, these "equal federations or horizontally-oriented organizations," in manufacturing industries were short-lived. Production and price schedules were hard 
to enforce and they failed to employ fully and effectively the existing resources of their members. Occasionally a federation dissolved into its original parts, more often it consolidated. This was more evident in those organizations troubled by concentration of control. Administratively, these consolidated structures provided for centralized planning, coordination, appraisal, and planning for its extended plant and personnel. A combination became administratively a consolidation only after its executive office began to do more than set prices and production schedules.

The loose alliance of manufacturing firms into a single consolidated organization with central headquarters made possible economies of scale through standardization in the procurement of materials (Chandler, 1962). Moreover, horizontal consolidation and centralization immediately created much more pressure for vertical integration than did mere combination. Coordination and the inability to build up an industry's own special market through brand names and advertising, and the development of products more nearly fitting the needs of the consumer was inhibited by this consolidated structure. Consequently, many firms began handling their own production and manufacturing.

As was previously mentioned, threats and other defensive reaons played a critical role in stimulating consolidation and integration. The resulting threat of unemployed resources and price- 
cutting, the need to apply resources effectively to changes in shortterm demand, and the desire to assume more satisfactory marketing facilities or to have a certain supply of stocks, raw materials and other supplies led to this strategy for expansion.

During the 1900 s the most dynamic and significant organizations became dominated by a few vertically integrated enterprises operating in national and often world markets. Small firms remained, but to exist they had to remain specialized or meet the needs of a local area (Chandler, 1962). When the managers of a "federation" or a combination of integrated companies decided to coordinate, appraise, and plan systematically their work, they almost always consolidated their activities into a single centralized functionally departmentalized organization. This rendered compliance with specifications as well as providing a communication network that linked all of the facilities involved in the industrial process with the customers' demands.

The fault with this structure, however, was that very few men were entrusted with a great number of complex decisions. As long as an enterprise existed in a stable environment, where there were no changes in sources of raw materials, markets, and production processes, they could remain centralized. Where technology, markets, and sources of supply were changing rapidly, the defects 
of the centralized structure became more obvious ${ }^{2}$ (Chandler, 1962). During the last two decades the growth of the multi-divisional "decentralized" structure came into existence. Diversification was most responsible for this decentralized form. It increased the level of complexity of both operational and entrapaneurial activities. In other words, if expansion resulted only in the development of a full line of goods that continued to use much the same type of resources, the reorganization of the marketing department so that it had an office for each major type of customer was usually sufficient. On the other hand, where business diversified into totally new lines serving a variety of people, decentralization emerged.

Conclusions. From this historical account of organizational expansion as it relates to business enterprises in the U.S., it is possible to see the environmental and technological influences affecting the kinds of decisions or strategies that these organizations took in terms of their structural design. These strategies made the transition from a single organization to a combination of integrated organizations, to a centralized departmentalized consolidated structure, and finally to a multi-divisional decentralized structure. It is

${ }^{2}$ For the past half-century most copper, zinc, tobacco, sugar, banana, and liquor companies have made much the same product for much the same type of user - they continued to run with the same centralized, functionally departmentalized form. (Chandler, 1962: p. 36) 
also interesting to note the fact that this pattern varies between organizations. There is no one right way to structure all complex organizations. Heterogeneity and dynamism of the environment make for the scattering of choice among many sub-units, but this depends to a certain degree on the organization's awareness of its effect on the environment. Chandler (1962) has pointed out that such organizations as the National Dairy recentralized when their markets became more nearly homogeneous due to such factors as urbanization and industrialization of the nation. On the other hand, many firms have recently decentralized as electronic data processing has increased; this decreases the time required to acquire knowledge about the environmental fluctuations and plan adjustments. This illustrates the fact that not only do organizations adapt to certain environmental constraints, but in many instances they are in a position to institute modifications to the context to maintain a preferred structure.

It is of particular interest in this study to note the environmental and technological factors which influenced the shift from a federation to a centralized structure such as competition and the need to standardize marketing procedures. This is not to say that when an organization is faced with these environmental and technological constraints it will automatically change in terms of its structural design. Quite the contrary, strategic growth results from an awareness by the organizational decision-maker of 
opportunities and needs - created by changing populations, income, and technology to employ existing or expanding resources more profitably. Thus, it was this awareness that influenced the strategy to centralize.

\section{Voluntary Organizations}

This section will describe how the history of voluntary organizations of the social service type have been affected by the evolution of American society and the environmental and technological factors accompanying this evolution. Voluntary organizations used in this description will be defined as "those organizations which have local affiliates or chapters throughout the country, have membership composed of volunteers, and depend on contributions as their main source of financing" (Sills, 1957: p. 14). As will become evident, changing social conditions have produced new problems thus creating occasions for the emergence of new voluntary organizations and influencing old ones to change their goals, much like the kinds of changes that the business organizations as described above went through. As technical expertise developed in American life, as the work in the voluntary organizations become more complex, as the leisure class volunteer disappeared, the voluntary organization in America became more professionalized and specialized. One way these organizations adapted to environmental constraints, therefore, was to form specialized 
units to face a limited range of contigiencies within a limited set of constraints ('Thompson, 1967).

The Early Volunteers. In the colonial period, the natural hazards of living made necessary a code of ethics that placed emphasis on industriousness and thrift, and which equated poverty and moral weakness with sin. We can trace our attitudes toward the rights and responsibilities of individual members in our society to these moral judgments which place a premium on independence and self - help.

It was not until the revolution and the coming of the industrial revolution that social welfare institutions were created to correct "social evils" (Seider, 1960: p. 5). As mentioned previously, this period marked a time of rapid growth in the population, and the change in migration patterns. People were moving to the cities in response to industrial growth and labor demands. The problems associated with the se environmental influences awakened moral consciousness and resulted in efforts to reform the individual and society.

The first volunteers belonged to the social class of industrialists and bankers who were influenced, to a certain extent, by religion. This group of people truly started the first charitable organizations in America, where emphasis was placed on "the wise 
giving of charity" (Seider, 1960: p. 5). Consequently, these first agencies grew out of personal interests of these wealthy individuals, and were inspired by local concerns or by growing national movements. Such organizations as the Children's Aid Society (formed in 1883 for the purpose of placing vagrant boys and girls with families in rural districts), the Young Men's Christian Association (this was originally developed for the purpose of placing boys in urban families), homes for unwed mothers, and such organizations as the B'nai B'rith (Sneider, 1966, p. 6).

During the Civil War, the institutionalization of charity was further developed as people were encouraged to support agencies rather than giving personal charity. In some progressive states public agencies began to emerge. These agencies set up welfare boards to stir indifference of church members to the terrible conditions of the poor in institutions. However, public aid was still neglected as private agencies began to flourish (Seider, 1960). In 1882, New York had approximately 194 private agencies giving relief (Seider, 1966). These agencies, in turn, operated on an uncoordinated basis. This created serious problems of duplication of services and inter-agency conflict. The Charity Organization Society of New York was established as a central registration to avoid duplication of services and to encourage inter-agency cooperation. These agencies had yet to combine into federations despite 
this effort to coordinate, appraise, and plan services on a statewide basis.

The 1900 s and the Expansion of the Voluntary Organization. With the great improvement in economic conditions in the early 1900 s, social reformers saw, in abundance, an opportunity to alleviate inadequate living conditions through a redistribution of wealth. The concern of people from all classes of society turned to the effect of low wages, child labor, and poor working conditions. Consequently, various private voluntary organizations began to flourish such as the YMCA, labor unions, federations of women's clubs, etc. (Seider, 1966). Citizen input made for a general understanding and involvement.

As these groups of citizens began to organize, the community became bewildered by the complexity of services and annoyed by the demands for contributions. Not only were the se agencies providing family child welfare, recreation, informal education, health and hospitals, mental health, and prison reform, but they were under the auspices of religious, non-sectarian, and public agencies. In order to bring order to chaos, the development of social planning emerged calling for joint consideration and coordination (Seider, 1966).

From Pittsburgh's first council of social agencies (1908) and Cleveland's federated fund raising body, the concept of coordination 
and integration of services, joint planning by agencies for new services, and federated efforts at fund raising gained impetus (Seider, 1966). The growth in population and technological complexity combined with the chaos as mentioned above, competition, and interagency conflict helped to influence these organizations to horizontally combine. Moreover, being that the primary responsibility for fund raising became more of a cross-section of the community, the control of the wealth shifted to more community control. All of this taken together, marked a shift to more of a horizontal line of control among the se voluntary organizations.

The Threat of War. In the development of voluntary organizations the move toward horizontal combination as a way of mobilizing community support became particularly apparent during World War I. At this time two national organizations were formed: the American Association of Community Funds and Councils of America Inc., and the United war activities fund (Seider, 1966). The latter brought together seven national agencies to establish a joint national budget, and to assign quotas to be raised by local war chests. This movement helped to expand the number of war chests throughout the country. It was also the first time that national board members and business leaders engaged in a national planning effort affecting local community services on a coordinated basis. Here is an example of a horizontally- 
oriented organization where the authority is delegated upwards and where the decision-making rested entirely on the agreement among the parties. This can be demonstrated by the fact that this organization was created by a group or people meeting together and appointing officers to act in the name of the organization, a distinguishing feature of a horizontally-oriented organization (Sills, 1957). In other words, the circumstances under which this organization was created most clearly demonstrates the direction in which the delegation of authority took place.

World War I witnessed another major development in the expansion of volunteer services under the American National Red Cross, organization first in 1881 . The initial objective of this organization, as set forth in its original constitution, was

... to hold itself in readiness in the event of war or any calamity great enough to be considered national, to inaugurate such practical measures in mitigation of such suffering, and for the protective of relief of the sick and the wounded as may be consistent with the objectives of the Association. (Sills, 1957: p. 262)

The American Red Cross started out very small in its early years, and flooding and disasters, the Spanish American War, and most importantly, World War I provided sufficient resources to make any expansion of its objectives unnecessary. The strategy for expansion, in turn, during World War I took the form of "vertical integration." It began to contract out professional services to public welfare 
agencies in more than 3,000 communities throughout the country (Seider, 1966). This is an example of a strategy where a single organization begins to expand and integrate by creating its own service organizations. This type of expansion also illustrates a more vertically-oriented type of organization where authority is being delegated downward.

After World War I this organization continued to expand, yet this occurred without any objective. Membership in the organization also began to decline. As James Thompson (1967) has stated, "multicomponent organizations subject to rationality norms will seek to grow until the least reducible component is approximately fully occupied." In integrating forward, much like the example of the American Red Cross, an organization has acquired distribution greater than its capacity. Sometimes the task environment cannot handle increased out-put. Thus, "Organizations with capacity in excess of what the task environment supports will seek to expand their domain" (Thompson, 1967). The American Red Cross expanded its domain by the adoption of a new program, "the preservation and improvement of Public Health" (Sills, 1957: p. 262). It became involved in giving relief during the beginnings of the depression of the $130 \mathrm{~s}$.

The prosperous years between World War I and the depression of the thirties was marked by a push toward specialization and 
professionalization more than the expansion of programs. In the traditional family and child agencies, volunteers were being excluded from direct contact with the client and were relegated to clerical tasks or to service on boards and committees (Seider, 1966). Because the task environment became more heterogeneous producing greater constraints for the organization, these organizations began to put boundaries around the scope of adaptation necessary by setting up specialized units. This enabled them to face a limited set of contingencies within a limited set of constraints (Thompson, 1967).

The Consolidation of the Voluntary Organization. The dis asterous depression years of the thirties served to consolidate many voluntary organizations and to set and raise standards of volunteer work. Standardization as a mechanism for coordination of services became even more pronounced. These agencies which were principally responsible for clarifying the se roles consisted of national organizations such as the Association of Junior Leagues of America, the National Council of Jewish Women, the Family Welfare Association of America, the National League for Public Health Nursing, etc. (Seider, 1966). Through these agencies specific opportunities for volunteers in the health and welfare field were defined, and principles for supervising were worked out. The National Committee on Volunteers in social work brought together social workers and volunteers 
to stimulate and improve volunteer service. This was accomplished locally through the organization of the volunteer bureaus, most of which formed a part or affiliated with the local council of social agencies (Seider, 1966). These bureaus, in turn, are the proto-type of the horizontally-oriented organization. They are examples of partnerships or coalitions of independent agencies on whose goodwill and support they depend (Perlman and Gurin, 1972).

The advances made in defining the role of the volunteer in depression times were tested and even further defined during World War II. The creation of the Office of Civilian Defense (OCD) influenced the disbandment of the independent Committee on Volunteers in social work. The job of coordinating became a more centralized task during war-time. This organization helped to coordinate the 4,300 civilian defense volunteer officers who had the responsibility for manning the protective and community war services. Most services in the social welfare field which were called upon to expand services to meet the needs of youth, women, the elderly, and handicapped workers pressed into wartime employment (Seider, 1966).

In 1944, the Association of Junior Leagues of America and the Community Chests and Councils of America, Inc., sponsored a joint study of post-war speculations for local centralized bureaus. The central concern behind this study was the awareness of the fact that maintenance of citizen contributions during peacetime (a time when 
there was no motivation for meeting wartime crisis with patriotic service) presented a serious problem. This move, in turn, called for national leadership which the Advisory Committee on Volunteer Service, established by the Community Chest and Councils of America, assumed responsibility. This became in 1945 the Advisory Committee on Citizen Participation, and which later (in 1951) became an important coordinating agency. It coordinated federations of voluntary organizations on a national level (Seider, 1966).

It should be noted, at this point, that the vertically and horizontally-oriented organizations refer to patterns which rarely exist in pure form, and that not all of these organizations conform perfectly to the classification as stated earlier. More specifically, none of the federations in the voluntary sector conform perfectly to the definition generally found in the literature, i.e., an affiliation of previously existing organizations. For example, the National Tuberculosis Association was founded in 1904 by a group of doctors and laymen and "much of the early Association staff was directed toward the organization of state tuberculosis associations" (Sills, 1957:p. 8). United Cerebral Palsy, another horizontally-oriented organization was founded in 1949 as an affiliation of local organizations, but most of the present affiliates were established through the encouragement of the national office. Despite the fact that the initiative for the establishment of the local chapters of these organizations came from the 
central national office, the process of growth and adaptation has led to a situation in which the balance of power lies in the local organizations. Their legitimation, therefore, comes from a local source. For this reason they are best classified as horizontally-oriented organizations.

The Foundation for Infantile Paralysis, formed in 1937 through the influence of President Roosevelt, illustrates a vertically-oriented type of organization. In creating the foundation, President Roosevelt delegated the responsibility for combating polio to others. From there, the Board of Trustees delegated the operating responsibilities to both a professional staff and to volunteers (Sills, 1957). It is important to note that this process of delegating authority involves the recognition and legitimation of individual initiatives such as the initiative of President Roosevelt as opposed to local or regional initiative. This, in turn, tends to alter the intentions of the delegators. As David Sills has pointed out,

This process of delegation is inherently paradoxical in nature. ... If you want something done right do it yourself, is the advice dictated by folk wisdom, but complexity and size of many organizational tasks makes this advice gratuitous. (Sills, 1957: p. 9)

With this in mind, organizations can be seen as being in a constant state of transformation - partly in response to certain environmental influences, and yet partly in response to the consequences which 
emerge from the process of delegation. Thus, it can be said that organizations formed by an individual or a small group (such as the Foundation for Infantile Paralysis) who appoint staff to help them carry out the task of the organization, and when its staff, in turn, creates committees, divisions, and branches, delegation is directed downward. As either the vertically-oriented organization (as described above) and the horizontally-oriented organization become more complex, and as both formal and informal rules are established, the patterns of delegation become more complicated. Situations may develop in which delegation goes both directions (Sills, 1957).

However, the funamental basis for this distinction between these two types of organizations is the focus of ultimate authority within the organization. In organizations having corporate-type of structures, the national headquarters exercises supervisory powers over the component units, while the federations in the affiliate retain a large measure of autonomy. This issue will be dealt with and elaborated on in the discussion of dependency.

Conclusions. Although there is much more to be said with regard to the history and origin of voluntary organizations, this brief summary has touched upon considerations involved in the development of both the vertically-oriented organization and the horizontallyoriented organization which have also illustrated to a certain extent 
the distinction between these two types of organizations. Moreover, this summary has illustrated some important variables which distinguish business enterprises and voluntary organizations.

As was mentioned previously, philanthropists, and reformers produced the first voluntary organizations which were dedicated to serving individuals. The original mission of most of these early organizations was to teach small voluntary societies how to give relief so as to avoid "pauperizing" people, while at the same time providing them proper, spiritual, friendly help. The basic ideology behind these organizations stressed the idea of "localism" and influenced in part the development of the horizontally-oriented organization. As these organizations began to expand, they added devices so as to avoid duplication, such as the development of coordinating and planning bodies to evaluate services on a local level. As part of the promotion of localism these coordinating bodies also influenced the public in terms of contributions to these local services. This latter point illustrates the fact that organizational decision-makers will try to influence the context so as to maintain a preferred structure. Through this influence on the public, they were able to maintain the horizontallyoriented structure, such as federations.

Business organizations, on the other hand, consolidated most of their federations into one organization or corporation so as to avoid competition among the se enterprises. Since competition, as 
opposed to cooperation, is built right into the rubric of business organizations, consolidation was a more likely route to take.

It is also interesting to note the fact that both business organizations and voluntary organizations are similar in how they went about developing ways in which they protected themselves against the organizational forces which have created them. Some of the devices were planned, some were adopted because they are generally accepted principles of administration, and still others were established more or less accidentally as a response to some operational problem which was not perceived by the decision-makers as being related to the broader problem of delegation. These control mechanisms do in fact serve to prevent goals of the organization from being unduly modified despite the fact that the organizational decision-maker may or may not be aware of the usefulness of these features.

As horizontally-oriented organizations developed from both internal forces (the delegation of authority) and external forces (the push toward localism), vertically-oriented organizations also developed from internal processes of delegation as well as external forces calling for a unified effort to solve or concede to a particular problem or "demand." This later point will become even more evident in the discussion on the development of government reliefgiving organizations. 


\section{Government Relief-Giving_Organizations}

As Francis Piven and Richard Cloward (1971) have pointed out, "The modernization of any society generally entails expansion of the power and authority of the national government." They have demonstrated through their historical analysis of relief-giving organizations in capitalist societies that during disruption in the economy it is usually local government that moderates the tremors by extending relief. The major decision-makers on a local level have the final say over relief arrangements. They are responsible for the necessary incremental adjustments.

As mentioned previously, organizations do not adapt easily, not only because of internal rigidities, but also because change requires that the fiscal support provided to institutions must be changed. For example, if local relief rolls rise, the local taxpayer becomes embittered by the rise of state taxes. Accordingly, the ability for local government to respond is inhibited while the expansion of the local relief systems strains and overloads the fiscal, administrative, and political underpinnings of the relief system. When the local system begins to break down, the government then responds.

Piven and Cloward also point out that,

The government will also intervene on local relief operations when the expansion of local relief begins to intrude on the operations of the labor market. (Piven and Cloward, 1971: p. 39) 
The government's usual response is to force "contraction" of relief. The federal government in the United States intervened to assume a massive expansion of relief during the great depression (and again in the $1960 \mathrm{~s}$ ), but more to contract relief arrangements, thus illustrating how an organization can institute modifications to the context in order to maintain a preferred structure, such as the maintenance of localized relief-giving organizations.

The following section will be concerned with a more detailed description of the history and origin or government controlled reliefgiving organizations. From this discussion certain common elements will become apparent among government controlled organizations with voluntary as well as business enterprises in terms of the influences on the development of administration in the United States. Where government controlled relief-giving organizations have diverged from these othe $r$ organizations relates to the ways that they have instituted modifications to the context so as to maintain a preferred structure.

The Early Development of Relief-Giving. Relief developed slowly in the United States. Except in the South, agriculture was conducted mainly by independent farmers on their own land; there was no large rural proletariate as in England (Piven and Cloward, 1971). Consequently, everyone looked out for their own. When industrialization did set in, it grew rapidly more or less absorbing the 
growing population. The open frontier land served, until the late nineteenth century, to drain off the deprived and the discontented. Thus, as Piven and Cloward have stated, "... there were no serious outbreaks of disorder so as to provoke relief concessions" (Piven and Cloward, 1971: p. 45).

The factors as stated above also helped to nurture the American belief in economic individualism, "The unshaken conviction held by the poor and the affluent alike that rags could be converted to riches" (Piven and Cloward, 1971: p. 46). On the one hand, this belief served to influence the large multi-departmental business organization. On the other hand, it served to limit or dampen the expansion of government controlled relief-giving organizations.

The doctrine of self-help through work, which distinguished nineteenth century capitalism, flourished in the U.S. Poverty in the U.S. came to be regarded as "the obvious consequence of sloth and sinfulness...the promise of America was not affluence, but independence, not ease but a chance to work for oneself to be self-supporting, and to win esteem through hard and honest labor" (Piven and Cloward, 1971: p. 47). The very notion of a relief system seemed blasphemous. As a consequence, what services that were in the way of relief were fragmented and scattered. Each township cared for its hungry in different ways, such as the giving of food, incarceration in almshouses or indentured services (Piven and Cloward, 1971). 
With urbanization and industrialization, various problems and diverse patterns of relief began to multiply. As was mentioned previously, most if not all of these patterns of relief had their source in voluntary organizations. Gradually a shift toward the institution of the almshouse or workhouse occurred. The first almshouse opened in Boston in 1740. By 1884 there were 600 in New England. Eventually states passed laws distinguishing almshouses as the primary method of caring for the poor. However, it remained for the local community to finance and operate them (Piven and Cloward, 1971).

The idea that poor relief, if it was given at all, was a local rather than a state or federal responsibility despite the hardships of immigration, migration, and cyclical depressions. Federal aid was periodically sought and given in cases of disasters such as floods and droughts, but not for the disaster of unemployment.

Early on in the twentieth century, the states began to establish pensions for the blind, the aged and widows. For the most part, these programs were not mandatory; implementation remained a local and usually a county prerogative (Piven and Cloward, 1971).

The Great Depression. When the Great Depression struck in the 1930s, almshouses, indentured services, and private charities remained the soul resource for the destitute. President Hoover limited himself to offering rhetorical encouragement to local charity 
efforts. In addition several resolutions introduced in Congress to aid victims of drought were defeated as was a measure to appropriate $\$ 25$ million for the Red Cross and unemployment relief (Piven and Cloward, 1971).

In 1931, with over 8 million people unemployed, the Emergency Committee for Employment was replaced by the President's Organization on Economic Relief. However, this organization mainly served to publicize the need for charity, to reaffirm the virtues of local responsibility, and to call for "coordination of local efforts" (Piven and Cloward, 1971: p. 51). In other words, they served to focus their attention away from mass destitution and toward the adminis trative confusion among the various local charities. Such agencies as the State Welfare Boards were developed which served not to give direct relief, but to coordinate local voluntary organizations.

Moreover, President Hoover's remedies for the difficult employment situation included such programs as block aid, where each block in the community cared for its own. This was in the early years of the depression. Another plan during Hoover's term in office was to share work by cutting work hours. However, workers were reluctant to share their meager earnings - in the 1930 payments in wages declined by 300 million dollars from the first quarter of 1929 to the first quarter of 1932 (Smith and Zeitz, 1970: p. 81). This economic decline was much more serious than anyone had 
assumed, yet the fears of a further business collapse led to the creation of the Reconstruction Finance Corporation, which provided loans to banks, life insurance companies, railroads, and other organizations. It permitted that loans be made to voluntary organizations, states for relief and to potential purchasers of farm commodities. In addition to the se strategies to stimulate the economy, Hoover also instituted the Home Loan Bank to enable homeowners to keep their property so as to promote new buildings (Smith and Zeitz, 1970). None of these measures had any impact on the economy which was characterized by overproduction and underconsumption.

The burden of public and private agencies became too great as unemployment spread and more and more people began to descend on relief agencies with pleas for aid. The Community Chest felt compelled to carry a large share of the load. They insisted in their public reports, even during the worse part of the depression, that they rather than government agencies were the appropriate vehicle to handle relief problems (Piven and Cloward, 1971). Most of the relief load was carried by local tax revenues. Reports from several major cities showed that relief expenditures by local cities had increased from $\$ 22,338,114$ in the first three months of 1929 to $\$ 73,751,300$ during the period of 1931 (Piven and Cloward, 1971). Municipalities had to strain to meet these escalating relief costs. Ad hoc schemes were developed in these localities to try and deal 
with this strain, such as taxing municipal employees the equivalent of a day's salary each month. As a result, tax revenues fell off sharply as municipalities tried to float bonds to pay for relief. Many localities had been brought to the verge of bankrupcy. The concept that the delegation of authority moves upward, and that relief is a local responsibility became ineffective as the environment became more heterogeneous and dynamic, creating too many constraints for a horizontally-oriented organization to adapt to.

Without work a way of life began to collapse, ... many began to define their hardships not as an individual fate, but as a collective disaster, not as a mark of individual failure, but as a fault of the system. (Piven and Cloward, 1971: p. 61)

As the legitimacy of economic arrangements weakened, anger and protest escalated. The depression thus gave rise to the largest movement of the unemployed in the history of this country.

On March 21, 1933 the destitute and the unemployed got relief. President Franklin Delano Roosevelt called for a Civilian Conservation Corp, a public works program, and federal emergency relief. All of these strategies to centralize government programs provided jobs for the millions unemployed. The Public Works Administration was then established in June of 1933 which served to provide jobs for the needy and for fuel to the economy (Smith and Zeitz, 1970) 
As the government became more aware that local relief and voluntary organizations could not handle the problems of relief, Congress approved the Federal Emergency Relief Act of 1933 which appropriated $\$ 500$ million to provide relief to an estimated 18 million people. Under the direction of Harry Hopkins, administrators and social workers were brought in to handle problems of managing such a large centralized operation. It was then decided that under the supervision of the FERA money would be given to states with the requirement that public agencies would administer funds given either on a matching basis to states or as direct grants in those instances where the governor proved that no funds were available. The policies thus established by the FERA were a significant break from the past and represented a changed philosophy about the responsibility of government for helping needy citizens (Smith and Zeitz, 1970). This strategy also represents the basis for the development of the "vertically oriented" organization among-relief giving agencies at the government level (where the authority is delegated from the federal to local levels.)

The passage of the Social Security Act of 1935 was the high point of social legislation during the New Deal. The program of public welfare, like other programs under the Social Security Act, had undergone a series of amendments to perfect the program, broaden coverage, and liberalize benefits. In addition, other social 
welfare programs which were assigned to a date prior to the Social Security Act were included in the 1935 legislation (Smith and Zeitz, 1970). Some were administered by the Social Security Board, others came under the jurisdiction of the Department of Labor, the U.S. Public Health Service and other federal and state administrative agencies. New responsibilities and additional money were provided to agencies administering programs under the Vocational Rehabilitation Act of 1920. The Children's Bureau, a part of the Department of Labor until 1946, initiated programs for crippled children and provided grants to states for promoting material and child health. All of these programs operated as federal-state cooperative ventures, only the insurance program for the aged was designed as a strictly federal operation which was administered by district offices irrespective of state boundaries.

Many have found it quite difficult to economically assess the New Deal. Such programs as the National Industrial Recovery Act undoubtedly contributed to business recovery. Regulatory legislation helped to restore confidence in banks and business recovery. Labor reform led to more humanitarian working conditions in factories. However, until World War II assured recovery by an expansion of government into the private sector, investments, income, employment, and profits never returned to World War II levels. 
World War II. The road of social change from Franklin D. Roosevelt's third inauguration in 1940 until the election of John F. Kennedy in 1960 was filled with indirection. Concern with winning World War II, negative reactions to the New Deal, fear of internal subversion and ineffective leadership made improvement of or innovation within social welfare institutions difficult. The nation rejected a program of national planning to prevent unemployment in 1946 . But in 1949, when unemployment claims increased by nearly one million because of a recession, a housing program aimed at creating jobs received congressional approval. Direct relief was therefore converted to work relief. Piven and Cloward have pointed out that, "As political stability was restored, relief practices in each locale are re-shaped day by day to meet manpower needs " (Piven and Cloward, 1971: p. 39). Thus, in the 50s a time of political stability, work relief was cut back and the unemployed were thrown upon state and local agencies once again.

The Turbulent $60 \mathrm{~s}$. The census bureau in 1970 reported that between 1959 and 1969 the number living in poverty in metropolitan areas increased from $44 \%$ to $51 \%$; there was a $42 \%$ drop in the number of white families below the poverty level while the decline for black families was 27\% (Smith and Zeitz, 1970: p. 176). During the $60 \mathrm{~s}$ the problems associated with this poverty consumed much of the 
energy of individuals concerned with social reform.

Politics during the decade were marked by an increasing sense of importance of technology in rational decision-making. Assassination of important political and moral leaders contributed to a sense of alienation among the population. Liberalism was accused of,

... maintaining economic growth through arms spending, of containing revolution through a series of limited police activities, and of buying off political discontents by building super highways and cars. (Smith and Zeitz, 1970: p. 196)

All of these factors contributed to political instability and turbulence which in turn had a dramatic impact on government-controlled reliefgiving organizations.

On the federal level, the government's focus in the mid 1960 s was on welfare rights. When the federal government intervened in local relief arrangements it did so not by directly liberalizing the existing welfare system, but indirectly through a series of new measures which had the consequence of mobilizing pressure against local relief arrangements. What emerged was a series of service programs for the "inner city" - the best known was the War on Poverty (Piven and Cloward, 1976).

In 1961 , ten million dollars was initially appropriated under the Juvenile Delinquency and Youth Offenses Control Act for grants 
to youth development projects for the prevention of juvenile delinquency. (Piven and Cloward, 1971) In 1963, the Community Mental Health Act authorized the expenditure of 150 million dollars to promote community centers in the cores of cities. A number of further programs evolved under the Johnson Administration. In 1964, Title II of the Economic Opportunity Act appropriated 350 million dollars to community action programs. In 1966, Title I of the Demonstration Cities and Metropolitan Development Act called for a comprehensive attack on the problems in urban areas such as slums, blight, unemployment, and coordination of federal, state, and local public private efforts.

Although each of these measures were later modified in response to feedback from Congress and various constituent groups such as AMA, each was launched as a distinct White House effort, and "each were thrust upon a Congress and a public that were at the outset virtually indifferent to the specifics of the legislation" (Piven and Cloward, 1971: p. 260).

There were many commonalties among all of the various programs launched by the federal government during the 1969s. Each program singled out the inner city as its main target. Each channeled some portion of its funds to new organizations in the inner city, circumventing municipal agencies which had traditionally controlled services. Most important, each made service agencies 
the target of reform. As Piven and Cloward have pointed out,

The hallmark of the Great Socieiy programs was the direct relationship between national government and the ghettos, a relationship in which both state and local government were undercut. (Piven and Cloward, 1971: p. 261)

A large portion of funds were diverted to a host of intermediaries other than local government including private agencies, universities, and new ghetto agencies. In addition, the federal government imposed specific guidelines for the use of these monies that were in fact funneled through these municipal agencies.

Strategy to Eliminate Poverty. At this point it is important to note the strategies that the United States has used in varying combinations to prevent poverty. One economist specializing in the study of income maintenance discerns four such strategies: make the system work, adapt the system to the needs of the poor, adapt the poor to the system, and relieve the distress of the poor (Advisory Commission on Intergovernmental Relations, 1966: p. 16).

1. Make the System Work. As was evident in the discussion of business as well as voluntary organizations, the government has played an important role in determining the structure and operation of the private economy. Functioning as active promoters of big business, they have influenced land-use patterns, transport and communication systems, and the advance of 
science. They have also intervened to smooth out swings in the business cycle, for example, the move toward regulation of business during the depression.

2. Adapt the System to the Needs of the Poor. Expanding suffrage and developing common citizenship have been common ways of adapting the system to the needs of the poor. Examples of the latter are criminal law and the laws of property and of torts and contracts, mechanics lien, and usery laws, industrial safety codes and anti-discrimination laws. Regulating the labor market by permitting and allowing collective bargaining on such matters as child labor, minimum wages and maximum hours have a close bearing on the needs of the poor. Social insurance and progressive taxation are other adaptations of the system to the needs of the poor.

3. Adapt the Poor to the System. Attempts to rehabilitate the poor have aimed at changing the attitudes, values, motivations, life-styles, and developing their potential productivity. In many instances the efforts of schools, churches, charitable organizations, and labor unions were designed to transplant middle class values and Protestant ethics to the poor in such terms that morality and personal salvation were equated with material success.

The use of broad community services is another 
emphasis in adapting the poor to the system. These services involved schools, libraries, hospitals, clinics, public housing, and sanitary improvements. Some public services have not only been "offered" but compelled as in the case of school attendance.

4. Relieve the Distress of the Poor. Usually considered the residual approach, sometimes this is regarded as complementary or an alternative to the other three. However, with the distinction between public assistance and social insurance becoming less clear, the fourth strategy is considered by some as the "weapon of the future" in the poverty war. Of the four major strategies in dealing with the problems of poverty, only the last two - adapting the poor to the system and relieving the distress of the poor - had their emphasis on the poor as a special group. Developing the economy and such measures as the extension of suffrage and collective bargaining were designed more to benefit the entire society than the impoverished as a target group. As mentioned before, the $60 \mathrm{~s}$ and the $30 \mathrm{~s}$ marked a time where the emphasis on national government involvement in the programs to eliminate poverty reached its peak. The contract compliance machinery and the legal powers of the federal government to provide equal employment opportunities for disadvantaged minority groups was significantly strengthened in the $60 \mathrm{~s}$. The Area 
Redevelopment Act of 1961 and the Manpower Development and Training Act of 1962 were aimed at revitalizing economically dis tressed communities and providing more vocational training for the underskilled. The Vocational Education Act of 1963 emphasized training for the disadvantaged, especially youth. Finally, in 1964 the Economic Opportunity Act provided funds and strategy for a coordinated and direct attack on the problems of poverty.

In 1964, the major issues that emerged in Congress concerned: 1) Imposing the anti-poverty program on existing agencies, 2) the issue of separation of church and state involved in the grant programs, 3) the issue of states rights which involved the philosophy of federalism and the question of Negro rights, and 4) the question of whether the program was really needed in the light of the healthy economic situation (Advisory Commission on Intergovernmental Relations, 1966). Consequently, amendments were made to the final act which departed from the general practice of federal grant-inaid programs by allowing communities the alternative of administering the community action program through a private non-profit agency.

The Johnson Years: Creative Federalism. During the Johnson Administration over 240 grant programs were enacted and as sistance dollars were more than doubled. With the exception of Medicare, all of the enactments during this time relied heavily on intergovernmental 
ways of implementing program objectives (Walker, 1974). Johnsonian emphasis on traditional aid programs provoked an array of governmental, quasi-governmental, and even private sector recipients of grant funds. Accompanying this was a near tripling of the direct and indirect flow of assistance funds to urban areas that by-passed states to local governments. As of early 1964 some 70 programs permitted direct disbursement to local governments (Walter, 1974).

The general thrust of the federal government can be seen as a move toward "Creative Federalism." To a certain extent, "Creative Federalism" is a variation of cooperative federalism which stresses partnership, the sharing of responsibilities and revenues, and finally, activism at all levels. The Creative Federalists during the Johnson years ostensibly placed heavy emphasis on rational goals while relying on categorical grants as a means of implementation. They had an expansive view of the system which included private sector participants. They also focused on goals rather than jurisdictions and placed emphasis on urban and city problems as much as rural and state concerns. By the close of the Creative Federalist years, nine out of every ten central cities in the largest metropolitan areas were receiving more federal aid on a per capita basis than their suburban counterparts (Walker, 1974).

The Move Toward Coordination. As the proliferation of 
government sponsored programs occurred, the need for coordination began to be felt by planners and administrators within the federal government. The government responded by moving to create an elaborate structure of coordination both in Washington and at the community level. They relied on a system of mutual adjustment rather than central direction upon what could be attained through negotiation among equals - rather than the exercise of central authority (Sunquist and Davis, 1969). James Thompson (1967) has pointed out that the autonomy of a group facilitates coordination by mutual adjustment, but that it is important to recognize that the autonomy is modified: A fully autonomous unit would not be or remain a part of the organization. Thompson (1967) described this state as being "conditionally autonomous." Under Creative Federalism, therefore, the unit or subset may have more decision-making power, yet it is still a part of a larger organization - a point which many Creative Federalists overlooked.

At the federal level, the government designated coordinators, each with responsibility for a particular field, but without power to enforce coordination. Recognizing that cabinet members cannot exert power over one another, the statutes governing their authorities proceeded in two ways: First of all, they authorized the coordinator to assist or advise the President in the exercise of presidential coordinating power. Secondly, they established mechanisms for lateral 
coordination and negotiations of agreements.

The first of the coordinators - the director of the office of Economic Opportunities (OEO) - was established by law in the Executive Office of the president in order that he might partake of the presidential coordinating authority. The President initially announced that the director would be the presidential chief-of-staff for the War on Poverty. However, there is no evidence that the President used him in the chief-of-staff capacity. OEO became absorbed instead in organizing and operating the Job Corps and setting up Community Action agencies. It became, in effect, one more verticallyoriented operating agency of the government. Consequently, on the matters of coordination, the directors of OEO negotiated with cabinet members as their equals, not as their superior (Sundquist and Davis, 1969).

An examination of the directives for the director of $O E O$, the Secretary of HUD, the Secretary of HEW, the Secretary of Labor, and the Secretary of Commerce shows an unavoidable overlapping of coordinating spheres. One coordinator is responsible, for example, of programs affecting urban areas, another for manpower programs, and still another is responsible for coordinating anti-poverty programs. The question can be raised: Is a program for the training of poor people in an urban ghetto a manpower program, an anti-poverty program, or a program affecting urban areas? Obviously it is all 
three, yet which coordinator is in charge? These kinds of jurisdictional disputes, however, were left to be settled by negotiation and voluntary acceptance of agreements among cabinet officers (Sundquist and Davis, 1969).

The proliferation of the vast expansion of federal public assistance programs in the 1960 s soon overwhelmed the local coordinating institutions that were in existence. In the absence of an organizational philosophy, no one solution was devised for the problem of community level coordination. By 1967, more than a dozen types of federally initiated local coordinating structures could be counted. These differed not just in structures and functions, but also in the elements of the communities' social and political structures upon which they were based. The cry for coordination that was rising from governors, mayors, and other participants in the federal system was directed less toward the need for coordinating federal programs as such than the need for bringing order to the maze of coordinating structures that the federal government was independently propogating (Sunquist and Davis, 1969).

The situation as outlined above regarding coordination as a strategy for urban problems is a continuation of a developing process with two previous stages. To reiterate what has been stated earlier, the first stage began with charity organizations and councils of social services and still later the health and welfare councils. Federal 
level intervention marked the second stage, the most comprehensive of which was the Model Cities Program. The third stage began during the Nixon administration. It includes the main outlines of the first earlier two, but adds an elaboration of technology and also the proliferation of federally sponsored structures providing local frameworks for comprehensive planning under $314 \mathrm{~b}$ and $70 \mathrm{l}$ planning funds, HUD's Annual Arrangement system, the Local Executive Review and Comment Program, and others as well (Warren (b), 1973).

Although these programs are all complex, they are all based on a simple rationale:

Programs to address the social problems of the city typically fall short of expectations because they are fragmented, wasteful, lack an overall plan or strategy, and in some cases are mutually contradictory. Planning must, therefore, be rational in relating means to ends, and in reducing contradictory goals, must be definite, and must involve all pertinent organizations in collaborative planning and implementing procedures. (Warren (b), 1973: p. 356)

The Model Cities Project provides an excellent example of all these ingredients in the coordination process. It offered the cities federal monies, called supplemental funds, if they could develop concentrated coordinated programs addressed to a broad spectrum of slum area problems with some form of participation by residents as being an essential ingredient.

As the programs began to develop two very important things 
happened. One was the election of a new administration (the Nixon Administration) which did not influence the development of the Model Cities Program and did not want it to continue. The other related to the fact that the results of the program showed little impact on the conditions of slum living. For the se two reasons the emphasis of the program was changed - the program was justified not for having bettered slum conditions, but for strengthening the cities ability for comprehensive planning and coordination.

Roland Warren sums up this strategy by the following statement:

Rather than look for alternative strategies, the conclusion is to invest more in the coordinative process. At present as indicated, the increased investment takes the form of elaborations of planning technology - the "hardware approach" and a proliferation of federal rubric for local coordination. This occurs despite the formidable weaknesses of the coordination strategy which has been pointed out from many sources in recent years. (Warren (b), 1973: p. 357)

The New Federalism. The Nixon-Ford Administrations marked a push toward the "New Federalism" which, as mentioned above, stressed local authority, the coordination of services, citizen participation, and greater discretion of state and local governments. The difference, however, between the Nixon-Ford strategy and that of the Kennedy-Johnson administrations was the strong support of decentralization of federal programs, the enactment of special 
revenue-sharing programs, a curbing of categorical grants-in-aid, a strengthening of general governments and politically accountable state and local officials, a strengthening of the service delivery system, and generally some sorting out of responsibilities for certain functions by governmental levels. Put another way, the New Federalism is basically a public shift in management from one style to another designed to bring public management closer to the participatory system. As defined by Rensis Likert, the participative system provides for full and free discussion between management and involvement; communication is up, down, and sideways; decisions are made throughout the system; there is little or no resistance to management; and control is widely shared (Wetle and Rice, 1974).

One of the major criticisms of the strategy proposed by the New Federalism is that it has not always adhered to its publicized principles. Decentralization of program authority to the field is only now beginning to effect big money grants. The effective organization of the Federal Regional Councils for major liaison efforts with the states and localities still face many hurdles. Among these hurdles is included the continuing weakness of their Chairman's positions and the variations in delegated discretion among the various field-units. In other words, the lines of communication throughout the system have not been clearly drawn which is a necessary aspect for the effective functioning of a decentralized system. The administration 
of the Partnership for Health and Safe Streets programs, the first two block grants programs, has been so ineffective that the latter now has a major categorical string attached to it, and the former is attached to several strings plus a major $\mathrm{HEW}$ effort to revamp it totally. Moreover, while general governments are supposed to be favored under New Federalism, federally encouraged single-purpose sub-state regional bodies have grown during the past six years to more than 1,800 (Walker, 1974).

Finally, the New Federalists realized that in order to decentralize, they first had to centralize. This led to an erosion of departmental and cabinet discretion and decision-making abilities while it strengthened the centralizing powers of the White House staff. (Walker, 1974) In short, practice has not always matched New Federalism precepts.

Summary. From this historical description of government controlled relief-giving organizations, a few general problem statements can be made which are relevant to what has been previously stated and to the perspective of this study:

1. A long series of wars and economic disasters such as the depression of the 30 s threatening our public system has led to the centralization of management at the federal level. Unfortunately, this has resulted in a deterioration of the 
management capability of the continuing decentralized systems, namely states and cities.

2. Our management system below the state level expanded rapidly with population increases to include 36,000 units of local government, the results of which can be viewed as too great a public decentralization for the effective delivery of most public services.

3. Vertical ties have strengthened over the last four decades, but the corporate system has not gone through adequate corresponding change to meet these public problems.

4. Our administrative and legislative branches have initiated a series of federal business management program changes during the last twenty years, the Area Agency on Aging (AAA) being one such program. Their stated purpose has been to decentralize the federal government or to "return power to the people."

5. The New Federalism design, initiated by President Nixon seems to lack a clear understanding and support from Congress and the balance of the vertical structure (states, cities, stock holders, and service receivers).

6. During the management centralization period of our recent history, state and city governments failed to develop their internal organizations to respond to changing service needs 
and problems. As each state and city became less able to provide an acceptable level of public service, the federal centralization process was reinforced. This has led to a high level of system frustration by public consumers, city mayors, state governors, and legislative bodies. From the citizen perspective, the most severe impact was felt by the low-income minority and disadvantaged groups such as the elderly, all of whom are least able to gain the attention of a centralized system. The intuitive turn has been toward citizen participation. However, this change came about without a corresponding change in worker acceptance, understanding, participation, and support for the need for such changes.

Conclusions. This section describing the origin of the expansion and development of business, voluntary, and governmentcontrolled relief-giving organizations has served to illustrate some of the environmental factors affecting these organizations as well as the strategies which these organizations chose so as to deal with their environment. Although this study deals specifically with governmentcontrolled organizations (Area Agencies on Aging), the description of business as well as voluntary organizations help to draw a clearer picture of the factors influencing the "vertically-oriented" organization. The following two sections will deal with organizational context 
in terms of dependency and interorganizational relations, both have a direct bearing on the description of the vertically-oriented organization.

Dependency

Based on a conception advanced by Richard Emerson, an organization is dependent on some aspect of its task environment, 1) in proportion to the organization's need for resources which that element can provide, and 2) in inverse proportion to the ability of these elements to provide the same resources. (Emerson, 1962) For instance, a branch of a welfare department which is totally dependent upon its parent organization for its resources, is dependent upon the state department of welfare to the extent that the branch needs financial resources and those resources are not available from other sources.

Dependence can also be seen as the obverse of power. Peter Blau (1964) has argued that actors or organizations involved in social exchange who are unable to reciprocate fully end up using compliance to the senior's wishes. According to this assumption "power is a generalized currency used to equilibrate exchange imbalances" (Jacobs, 1974: p. 48). For example, the branch of the welfare department, who may need resources from the parent organization but who is unable to give anything in return, ends up giving compliance to 
the parent organization's wishes.

Blau, in turn, made an important contribution to Emerson's work. He pointed out the existence of coersion as a means to influence. Power and control then can be thought of in terms of vulnerability as well as dependence. The following Table sums up strategies of both the dependent and dominant parties in an unbalanced exchange relationship.

TABLE I

A SUMMARY OF EXCHANGE AND POWER

\begin{tabular}{lll}
\hline $\begin{array}{l}\text { Alternatives for Com- } \\
\text { pliance for the Depen- } \\
\text { dent }\end{array}$ & $\begin{array}{l}\text { Conditions of } \\
\text { Independence }\end{array}$ & $\begin{array}{l}\text { Strategies of the } \\
\text { Dominant }\end{array}$ \\
\hline \hline $\begin{array}{l}\text { 1. Supply powerholder } \\
\text { other inducements }\end{array}$ & $\begin{array}{l}\text { Availability of } \\
\text { strategic resources }\end{array}$ & $\begin{array}{l}\text { Remain indifferent } \\
\text { to what dependent } \\
\text { offers }\end{array}$ \\
\hline $\begin{array}{l}\text { 2. Obtain scarce re- } \\
\text { wards elsewhere }\end{array}$ & $\begin{array}{l}\text { Alternative sources } \\
\text { of supply for scarce } \\
\text { rewards }\end{array}$ & $\begin{array}{l}\text { Maintain monopoly } \\
\text { over what dependent } \\
\text { needs }\end{array}$ \\
\hline $\begin{array}{l}\text { 3ake scarce goods } \\
\text { by force }\end{array}$ & Coercive force & $\begin{array}{l}\text { Maintain law and } \\
\text { order }\end{array}$ \\
\hline \begin{tabular}{l} 
Do without \\
\hline
\end{tabular} & $\begin{array}{l}\text { Ideals defining } \\
\text { scarce rewards as } \\
\text { unnecessary }\end{array}$ & $\begin{array}{l}\text { Sustain values which } \\
\text { define particular } \\
\text { scarce rewards as } \\
\text { necessities }\end{array}$ \\
\hline
\end{tabular}

Blau, 1964: p. 124 
This approach to dependence and power has several advantages to the study of organizations. It leads to the consideration of relationships between the organization and the several elements of its pluralistic task environment. Thus, an organization may be relatively powerful in relation to those who supply its inputs and relatively powerless in relation to those who receive its outputs or visa-versa. On the other hand, an organization may be powerful in terms of both its outputs and inputs.

Those organizations who are relatively powerless on all sectors of its task environment usually end up catering to whatever fleeting interests of an unstable population it could activate at a particular time (Thompson, 1967).

Finally, the power-dependence concept as indicated by this approach provides an important deviation from Emerson's concept of power which assumes that the power of one organization is at the expense of another. By taking into consideration the concept of interdependence, we admit to the possibility that two organizations may become increasingly powerful with regard to each other. It is this possibility upon which coalitions rest.

Viewing dependence in this context, also calls into question the closed system models of organizations since, as mentioned previously, the open-systems model explicitly includes organizationenvironment relations in the assessment of the effectiveness of a 
given structure. Since the conditions promoting organizational dependence and independence vary over time and organizational contexts, it is likely that under different organizational conditions different forms of structure will facilitate the bargaining position of the organization. By critiquing the work of the Aston Group study conducted by Pugh, Hickson, and their associates (1969) this point will become more apparent.

In this study, 52 organizations in Birmingham, England were studied. Fourty-six of the 52 organizations were randomly sampled and were used in the analytic phase of their study. Dependence, one of the weaker points in this study, was conceptualized as either relationships with the parent organization and/or relations with other organizations. The former was considered the most important. It was operationalized by 1) the relative size of the focal organization in relation to the parent organization; 2) the status of the focal organization in its group, that is whether it was an independent organization, a subsidy with legal identity, a head branch, or a branch; 3) the representation of the focal organization in the policy-making bodies of the parent organization; and 4) the number of specializations contracted outside the focal organization, both from the parent organization and from other organizations.

Dependence on other organizations was operationalized using five scales: 1) Integration with suppliers in terms of ownership and 
contractual ties, 2) response to the focal organization to customer influence, 3) integration with customers in terms of ownership and contractual ties, 4) percentage of the focal organizations output volume consumed by its largest customer, and 5) percentage of the largest customer's needs supplied by the focal organization.

The operationalization of dependence also included: 1) The origin of the organization - was it founded by individuals or by another organization? And 2) the public accountability of the parent organization - whether it was quoted in the stock exchange or whether it was a government department, the latter being more publicly accountable.

Briefly summing up the results, the study found that those organizations who scored highest on dependence were publicly accountable, such as government departments founded by another organization with a large number of specializations contracted out, vertically integrated, small in size relative to the parent organization, low in status, and not represented at the policy level. They also found that dependent organizations have a more centralized authority structure and tend to standardize procedures for advancement and selection. They conclude, in turn, that,

... dependence of an organization reflects its relations with othe $r$ organizations in its social environment, such as suppliers, customers, competitors, labor unions, management organizations, and political and social organizations. (Pugh, et al, 1969: p. 104) 
While it may be that more dependent organizations demonstrate these characteristics, Pugh and his associates did not carry through their distinction between dependency on parent organizations'dependencies on other organizations. This is a very important distinction due in part to the different resources sought from these two sources. From the parent organization, the focal organization needs financial resources and usually seeks autonomy in decision-making so that its administrators can make decisions on their own. From other organizations, especially suppliers, customers and competitors, the organization needs raw materials, a market for its products or services, and a large enough share of the market to survive (Mindlin and Aldrich, 1975). This distinction needs to be made in any analysis of dependence. However, in computing dependence scores for each organization as well as analyzing the relation of dependence to other structural barriers, the Aston group made no further reference to the two forms of dependence and ceased to make the distinction in their writing.

Dependence and Inward Orientation. Following along the assumption that organizational decision-makers are typically oriented to an adequate supply of resources, and that this orientation becomes, for organizational decision-makers, an operational definition of the purposes of the organization and thus of their responsibilities as 
decision-makers, then we can assume that because vertically-oriented organizations are dependent upon the parent organization for virtually all of its resources, they will be independent of other organizations in their functional and geographic community. In other words, because of this dependency on a single organization outside of the community, the vertically-oriented organization expends a great deal of its energy complying to the parent body. Consequently, most of its concerns will be focused inwardly rather than on interorganizational activities.

Burton Gummer, in his study of a welfare agency (an organization which was dependent upon a parent organization for the vast supply of its resources) analyzed the responses of the personnel in the department to a questionnaire which asked what they thought their unique competence was in their jobs. Content analysis produced the following four categories:

1. The services provided by the respondent's unit, such as family counseling, housing, home management, etc.;

2. the worker's skill in helping people;

3. knowledge of public welfare procedures; and

4. knowledge of community resources.

Nearly one-half of the 27 line workers listed either service of the unit, worker's skill or knowledge of agency procedures as their unique competence, while only three listed knowledge of community resources. The remaining nine listed a wide range of activities as their 
unique competence. This suggests that the model orientation of the line workers is toward activities performed in the organization (Gummer, 1975).

Even more significant was his findings with regard to the agency's hierarchy. At the supervisory level only two of the five unit supervisors specifically mentioned knowledge of community resources as a unique competence, and only one of the five developed guidelines for interorganizational activities in the unit. At the level of the executive and deputy executive positions, the orientation was entirely toward agency operations. This evidence combined with the findings of Levine and White's study (1961) and that of Levine, White, and Paul (1969) point to the conclusion that vertically-oriented organizations are more dependent upon a resource base outside the community, and less dependent upon those organizations in a functional and geographic community.

As mentioned above, all organizations must have external support to exist, and to get this support organizations must be perceived as functional by those whose support they depend on, i.e., they must be accountable to those organizations who are the providers of resources. Survival, however, is not the only concern of the organization. Another concern is the organization's effectiveness. In this model, activities are evaluated in terms of whether they further a particular goal. What is common about the survival 
model and the effectiveness model is that activities and goals are the primary means by which organizations establish themselves in the environment. They are critical to both their existence and role definition. To the extent to which the organization must demonstrate that their activities are functional for the ends of those who are supporting them, the two models converge. Given this perspective, part of the inward orientation characterized by the vertically-oriented organization is subsumed with the legitimization of its stated goals. According to John Tropman, organizations that expend much effort on the legitimation of goals, per se, exhibit a lack of a concrete planning or action output - they may become dominated by maintenance needs. This is particularly apparent among vertically-oriented organizations and causes to a certain extent serious problems in terms of service delivery (Rothman, 1974: p. 140).

Control of Dependence. As noted earlier, the task environment is defined by the dependence of the organization. Since dependence introduces constraints and contingencies, the problem for the organization is to avoid becoming subservient to elements of the task environment. James Thompson has propositioned that: "When support capacity is concentrated in one or a few elements of the task environment, organizations under norms of rationality seek power relative to those whom they depend on " (Thompson, 1967: p. 34). What is 
expected from this proposition, therefore, is that organizations subject to rationality norms and constrained by monopolized capacity for support, such as in the case of the vertically-oriented organization, will strategize toward achieving power to off set their dependence. The question then is how to achieve power when the environment does not offer many alternative sources support.

When organizations establish domains, they acquire dependence. However, as stated above, the acquisition of dependence is not so easy. In the management of the attempt to gain power with respect to some element in the task environment, organizations employ cooperative strategies (Thompson and McEwen, 1958). To accomplish this, the organization must be able to demonsrate its capacity to reduce uncertainty for that element, and must make a commitment to exchange that capacity.

Thus, an agreement between $A$ and $B$, specifying that $A$ will supply and B will purchase reduces uncertainty for both. A has more knowledge about its output targets and $B$ about its inputs. Likewise, the affiliation of a private non-profit drug program with a county mental health clinic reduces uncertainty for both. The drug program will have increased assurance that it has the resources to operate, and the mental health clinic will have the assurance that it is satisfying a mandate to provide services to drug-dependent individuals. Consequently, the mental health clinic is able to 
establish power with respect to its source of dependency, that being the state mental health division.

By using cooperative strategies the effective achievement rests on the exchange of commitments for the reduction of uncertainties for both parties. But commitments are obtained by giving commitments. These commitments are a two-way street, and management of interdependencies confront the organization with dilemmas. The use of contracting, coopting, and coalescing presents a set of alternatives to the organization, and represent different degrees of cooperation and commitment.

Contracting refers here to the negotiation of an agreement for the exchange of performances in the future. This usage is not restricted to those agreements which legal bodies would recognize. It includes the kind of agreements between the drug program and the county mental health clinic as illustrated above. It also covers the understanding between a university and a donor involving, for example, the naming of buildings. Contractual agreements thus may rest on the faith and the belief that the other will perform in order to maintain a reputation or prestige. In the case of the vertically-oriented organization this is one way in which they can reduce their dependency on the parent organization.

Recently, the federal government has gotten wise, so to speak, to this strategy and has placed a mandate on certain 
coordinating bodies to form these contractual agreements with other organizations. This is designed, in effect, to reduce the organization's dependence upon the parent organization and thus facilitate the delivery of services. However, fitting into the proposition that organizations that expend much effort on legitimation of goals, per se, such as gaining public approval for existence exhibit a lack of concrete planning or action output, then one would expect that this mandate would be ineffective in accomplishing its stated purpose. In other words, with this mandate, one would expect the organization to expend too much energy legitimizing itself through contractual arrangements rather than acting. Consequently, a contradiction is placed on the organization with this stipulation as a condition for the receipt of funds.

Burton Gummer (1975) illustrated the low level of activity in this area for the branch public welfare agency despite the importance attached to contractual arrangements for the delivery of service in the official guidelines.

Coopting has been defined as, "The process of absorbing new elements into the leadership or policy-determining structure of an organization as a means of averting threats to its stability or existence "(Thompson, 1967: p. 35). Cooptation increases the certainty of future support by the organization coopted. The acceptance of the corporation's board of directors of representatives of financial 
institutions, for example, increases the likelihood of access to financial resources for the duration of the cooptive arrangement. The drawback to this alternative to reducing dependency is that it places an element of the environment in a position to raise questions and perhaps exert influence on other aspects of the organization. For vertically-oriented organizations, this is a risky move to take in terms of its own survival.

Coalescing refers to a combination or a joint activity with another organization or organizations in the environment. To the extent that the coalition is operative, the organizations involved act as one with respect to certain operational goals. "Coalitions not only provide a basis for exchange, but also require commitments for future decision-making " (Thompson, 1967: p. 35). This strategy to decrease dependency is a more constraining form than coopting, and is therefore an unfeasible strategy for a vertically-oriented organization. This point, in turn, will be stressed in the next section discussing interorganizational variables such as frequency of interaction and joint decision-making.

A final criticism of the use of cooperative strategies centers on the fact that many programs intended to provide enhanced cooperation between agencies fail because cooperation is sought without attending to underlying power relations (Benson, 1975). A good example of such a situation is the Cooperative Area Manpower Planning 
System which is designed to produce coordination among manpower programs. This program failed because it relied upon voluntary cooperation of participant organizations and provided for no change in the underlying political-economic forces which had previously kept the agencies apart. Much of this has to do with the structure of the coordinating agency vis a vis its major provider of resources.

ORGANIZATIONAL RELATIONS: FREQUENCY OF INTERACTION

This section will be concerned with interorganizational relations in terms of frequency of interaction. ${ }^{3}$ An attempt will be made to describe, in more detail, some of the theoretical basis for much of the research in this area. From this description several implications can be drawn with regard to the vertically-oriented organizations and their relationship with organizations in a particular network.

\section{Exchange Theory}

Levine and White (1961) have stated that the interdependence of the parts of the exchange system is contingent upon three related factors: 1) The accessibility of each organization to necessary

${ }^{3}$ Frequency of interaction has been defined as, "The amount of contact between organizations to be measured in relation to an organization's total contacts with others." (Aldrich, 1973: p. 64) 
resources outside a particular system, 2) the objectives of the organization and particular functions to which it allocates the resources it controls, and 3) the degree to which domain consensus exists among the various organizations. They go on to illustrate how each of the se three factors affect the exchange of elements among organizations.

As illustrated in the previous section, the various parts (or organizations) of a system can be differentiated from each other in terms of their relative dependence upon other parts of the system. To reiterate, certain parts are relatively dependent, not having access to elements outside the system which is characterized by the horizontally-oriented organization, whereas others, which have access to elements outside the system, possess a high degree of independence or "functional autonomy." (Gouldner, 1960).

In their study of health organizations, Levine and White (1961) found that those organizations who are relatively autonomous from the rest of the organizations in a particular system, and thus possess a high degree of independence, tend to interact less with other local agencies than those who are dependent upon the system for their needed resources. An examination of the four vertically-oriented organizations, in their study, reveals that three of them give resources to other programs to carry out their activities and the fourth conducts broad educational programs. They point out that such functions tend to involve less relationships with other organizations 
than those that provide direct services.

They also point out, that the vertically-oriented organization may at times produce specific disagreements with other agencies in the system. This is demonstrated by the criticisms from the local health system toward a community branch of an official state rehabilitation program. The rehabilitation program in order to justify its existence to the legislature had to show that a certain number of persons had been successfully rehabilitated. In other words, the services by this program had to successfully return to self-supporting roles a certain number of its debilitated clients. In order to accomplish this the rehabilitation program has to accept a select group of people causing a great deal of frustration among the local system. The frustration relates to the fact that other agencies are unable to get the state to accept their debilitated clients for rehabilitation. In the eyes of these other agencies, the state rehabilitation agency is remiss in fulfilling its goals. Because the state agency has to survive, it is more concerned with its relationship to the legislators who control the "purse strings" than to the rest of the system. Given the definition of the organization's goals, and the state agency's relative independence of the local health system, its interaction with other organizations is relatively low.

Levine, White, and Paul (1963), in their study of 68 voluntary health care agencies in four communities point out some of the 
problems facing the delivery of health services due to the multiple sources of authority. On the one hand, the re are agencies like the National Foundation, American Heart Association, and the American Cancer Society where the authority is delegated downward from the national or state organization to the local chapter. These organizations are referred to in this perspective as having vertical orientations or corporate structures. On the other hand, there are organizations with horizontally-oriented structures such as the Visiting Nurses Association and the Family Services which delegate authority to the state and national levels. These horizontally-oriented organizations in this perspective are more geared toward the needs of the local community.

Given such diverse sources of athority, then it is understandable why maximal inter-agency cooperation is not always attained. As a result, of these divergent sources of authority, and for many other reasons as well, organizations in the health and welfare system have varying goals which often times conflict. Agencies differ in the standards they employ to evaluate success and the means they use to achieve their objectives.

They point out, in turn, that the importance of conflicting goals, especially those from outside the system, are particularly evident when it comes to fund raising. For example, verticallyoriented organizations such as the American Cancer Society resist 
pleas of horizontally-oriented fund raising advocates and carry out their own fund raising campaign. Moreover, these vertically-oriented organizations are frequently under attack by agency personnel and board members for not spending a greater amount of their collected funds for local services. They illustrate the fact that much of this clamor and controversy relates to the varying goals and objectives of these agencies. Vertically-oriented organizations requiring greater centralization of resources on the federal level are understandably alert to activities on the local level which may impede the flow of sufficient funds to the national body. In other words, these organizations in their fund raising drive view the health picture from a national vantage point. While the local chapters are oriented partly to their respective community, the authority of these local affiliates is limited by the priorities established by national headquarters. By contrast, organizations such as the Community Chest and the United Funds (both horizontally-oriented organizations) are geared more toward the local community per se. Given the fact that these two organizations have different goals and objectives, it is understandable why they have difficulty interacting with one another.

\section{Organizational Interdependencies}

Both of these studies point out a very real problem facing the. vertically-oriented organizations in terms of a low level of inter- 
action with other organizations in a given community, yet their definition of interdependency is extremely narrow. As Aiken and Hage (1968) have pointed out, studies of organizational interdependencies such as these essentially conceive of the organization as an entity that needs inputs and provides outputs, linking together a number of organizations by mechanisms of exchange or transactions. Linkages between organizations, however, are conceived of in a variety of ways; passage of information, transfers of clients or funds or the input-output exchange as mentioned above, and sharing of facilities. Looking at the se forms of linkages as a continuum of interdependence, then passage of information would have relatively low interdependence, while the sharing of facilities or joint activities would have relatively high interdependence. What is implied is that joint programming, as a definition for interdependence, makes an implicit technological assumption that the production process requires joint efforts that transcend organizational boundaries thus involving a lessening of organizational autonomy. Because organizations like to maintain their autonomy, the re is a natural tendency for organizations to avoid creating interdependencies except in relatively safe areas that are auxilliary to the main objectives. Jerald Hage (1975) gives the example of Welfare organizations who will join into joint activities which have relatively little to do with their objectives, for instance, such activities as education and research. 
At this point it is important to distinguish the joint program from the joint organization. The latter refers to a situation in which two or more organizations create a separate organization for some common purpose. For example, the Community Chest was created by the health welfare agencies for fund raising purposes. Business organizations have created joint organizations so as to provide service functions. These examples clearly illustrate the difference between a joint program and a joint organization, the latter having separate corporate identities and quite often their own staff, budgets, and objectives. Some examples of joint programs would be the student exchange program among Harvard, Yale, Columbia, and Cornell Universities. Among business organizations, Ford and Mobile have begun a joint research project designed to develop superior gasoline. Burton Gummer (1975), in his study of the interorganizational relationships of a public welfare agency, operationalized his dependent variable (contacts with other organizations) by focusing on the extent to which these contacts are indicative of a sharing of resources between organizations with a consequent heightening or organizational interdependence. The underlying continuum used in this context is the degree to which the sharing of resources involves a lessening of organizational autonomy, particularly in the area of internal decisionmaking processes. Consequently, at one end of the continuum he focused on exchanges that involve little or no infringements on 
organizational autonomy such as the sharing of information about one's own service or the gaining of information regarding another organization's activities. At the other end of the continuum are exchanges that involve a major inroad into the internal decision-making process such as joint programs. This variable, therefore, was termed "purpose of contact" and was measured at an ordinal level: Information (low interdependence), Service (moderate interdependence), and Joint Activity (high interdependence).

By information, the respondents were asked whether their contacts with other organizations involved telephone contacts, informal meetings, and/or letters for the sole purpose of obtaining information. By service, respondents were asked about referrals to other agencies, follow-up, contacts after referrals, acting as an intermediary to facilitate obtaining services for a client, and informal meetings about a client as a primary source of contacts with other agencies. Finally, respondents were asked whether these contacts involved formal case management in which joint decisionmaking occurred, the development of joint services such as a common intake, and contractual arrangements to purchase services from other organizations. 4

${ }^{4}$ Note: Aiken and Hage argue that the purchase of services does not fit into the category of joint activity because it does not affect the internal decision-making structure of an organization. However, Gummer points out that the experience of the social welfare field, 
The overall conclusion that Gummer reached after analyzing his data is that, while the public welfare agency personnel engaged in extensive contacts with other agencies, the intensity of these contacts in terms of the number of contacts with any one agency was not that great. Over three-fourths of the contacts fell into the low contact rate category, meaning that the vast majority of the agencies contacted were made by a few workers and on an infrequent basis. Furthermore, the data reveals that the overwhelming bulk of contacts were for the purpose of obtaining service for clients. This study, in turn, illustrated the fact that the vertically-oriented organization will be less likely to be involved in interaction which involve a high degree of interdependence (joint activities).

John Clark and Richard Hall (1974), in their research involving organizations concerned with problem youth, also shed some light on the area of interorganizational relations, especially in the area of frequency of interactions, which provide some strong implications to Gummer's work. The design of their study involved asking these organizations about the nature of interorganizational relations. These detailed questions were an attempt to quantify the particularly the relationship of the federal government to state and local governments via the grant-in-aid programs, suggests otherwise. The purchaser of service is in a position to exert some influence on the internal decision-making structure of the provider organization by imposing requirements on how the service should be provided, who should receive them, and under what conditions. 
quality of the relationships with each organization. Each respondent was asked to indicate the frequency and importance of their organization's contacts in this particular network.

The results of the study showed that: 1) Conflict between organizations is positively related to good communication as is frequency of interactions; 2) coordination efforts are rather strongly associated with such factors as availability of personnel, the importance of contacts, compatible operating philosophies, the assessment of good performance on the part of the other agencies, and the assessment that the other organizations have competent personnel; and 3) coordination is also positively related with good communication, suggesting that communications can play a dual role in leading to coordination and being part of conflict situations. Generally, this study pointed out that frequency of interaction, in terms of the intensity of contacts made to other organizations in a network, is positively related to coordination, communication, and conflict. In this case, frequency of interaction does seem to lead to better and more coordinated efforts, at the same time it leads to conflict. Given the results which Gummer found in his study, then one could conclude that the vertically-oriented organization such as the welfare branch, would be less likely to be involved in coordinated efforts with other organizations in a network, that is, efforts such as joint programs. Aiken and Hage (1968) in their study of sixteen human service 
organizations, examine the issues involved in the following proposition: "Organizations having many joint programs with other organizations tend to be more complex, more innovative, have more internal communication channels, and have slightly more decentralized decision-making channels." (Rothman, 1974: p. 116) Their implicit assumption is that complexity (namely a high degree of professionalization and diversity of occupations) leads to intensified communication between different occupations, which consequently enriches the organizational package of ideas, programs, etc. Because the vertically-oriented organization is less likely to be involved in joint programs then one would expect these organizations to be less innovative, have a more centralized decision-making structure, have less internal communication, and tend to be more formalized.

Howard Aldrich (1973) in his theoretical model propositioned that the concentration of resources in a given network of organizations attracts those organizations which seek to exploit the resources by entering into more frequent interaction with the organization holding those resources. By looking at resources in terms of money and authority (legitimation), it is possible to see the dispersion of resources in a given network of organizations where some are verticallyoriented organizations. Following along Aldrich's proposition, it is possible to see why the vertically-oriented organization does not enter into frequent interactions with other organizations, i.e., they are not 
attracted to exploit the resources in a given community. Aldrich went on to show that a high frequency of interaction leads to the development of formalized relations (on an interorganizational level) as organizational learning takes place and each organization gives recognition to the transaction. ${ }^{5}$ Formalized relations, according to Aldrich's theory, lead to a stabilizing effect on the environment, i.e., the degree of turnover in the elements of the task environment. If one follows along with what has been presented then this proposition has several implications for the vertically-oriented organization, that is, they will be less likely to give formal recognition to transactions made to other organizations in a given network, thus presenting instability to the environment.

\section{PROPOSITIONS CONCERNING THE VERTICALLY-ORIENTED ORGANIZATION}

Based on what has been stated throughout this theoretical description, the following are a set of propositions which try to sum up the characteristics of the vertically-oriented organization:

${ }^{5}$ Note: Aldrich defines formalization as: 1) The extent to which the transaction between two organizations or groups is given official recognition, for example, if agreements are legislatively mandated or at the other end of the continuum, if they are ad hoc or informal; and 2) the extent to which an intermediary coordinates the relationship. 
Proposition 1. Where there are organizations formed by an individual or a small group (vertically-oriented organizations) who appoint staff, and when staff creates committees divisions, and branches, the delegation of authority is directed downward.

Proposition 2. Where authority runs downward from the federal or state to local level (such as in the vertically-oriented organization) the ultimate control of resources and the decision-making within the organization rests with national headquarters, i.e., it is "conditionally autonomous."

Proposition 3. Because the vertically-oriented organization is dependent upon a parent body for virtually all of its resources and is unable to reciprocate fully, it ends up using compliance to the senior's wishes.

Proposition 4. Because the vertically-oriented organization is constrained by a central authority, they will be less likely to control dependency through cooperation strategies such as cooptation and coalition formation.

Proposition 5. Because the vertically-oriented organization expends much effort on the legitimation of goals they lack a concrete planning or action output - they become dominated by maintenance needs.

Proposition 6. Because the vertically-oriented organization becomes dominated by internal concerns, they are less likely to become involved in intense interactions (i.e., joint activities) with other organizations in their functional and geographical community.

Proposition 7. Finally, vertically-oriented organizations, because they are less likely to become involved in joint 
programs will less likely become involved in coordinated efforts with other organizations.

From these propositions a structural explanation for the causes of interorganizational coordination is offered. Namely, the organization's capacity to engage in interorganizational activities will be a function of its location vis-a-vis its major providers of resources. The serious problem of fragmentation among the human service delivery system is due in part to those organizations in a verticallyoriented structure, and their inability to interact with other organizations in their locality.

Summary. To summarize what has been stated thus far, the vertically-oriented organization illustrates certain distinguishing characteristics: They exist in a larger structure where the authority flows downward and where the ultimate source of authority rests on either the federal or state level. Finally, they are accountable to the parent organization (they have certain stipulations and/or mandates placed on them by the parent body as a condition for the receipt of funds.) From these characteristics, certain behaviors can be anticipated in terms of the vertically-oriented organization's internal as well as external concerns and activities. The propositions as stated above exemplify, to a certain degree, these characteristics (propositions 1-2) and the anticipated behavior (propositions $3-7$ ). 


\section{CHAPTER IV}

\section{THE AREA AGENCY ON AGING: CASE MATERIAL}

The Area Agency on Aging, a program developed out of Title III of the Older Americans Act (1973), was chosen as an example of the vertically-oriented organization, and thus will be used as case material supporting the above mentioned propositions. The unique feature about this organization, aside from its vertical ties with the federal government, is that it was specifically designed to promote horizontal relations in the area from which it will operate. It is thus the latest federal attempt to devise a system which will insure the delivery of coordinated services to the elderly. Given the fact that this organization resembles a vertically-oriented organization, then one would expect that it would be more concerned with internal survival, and thus less likely to be involved in intense interorganizational activities. It is the assumption of this analysis, therefore, that this organization would be ineffective in reaching its stated goals which focus on the coordination of services for the elderly for the purpose of promoting independent functioning in their home environment.

Based on the propositions as stated earlier, the following section will attempt to demonstrate the Area Agency on Aging's 
resemblances to the vertically-oriented organization in terms of the direction and source of authority, the issue of accountability (who conrols the vast bulk of money and authority), and the anticipated behavior of the Area Agency on Aging. To help substantiate the se propositions concerning the anticipated behavior of the Area Agency on Aging (AAA) a few select responses from a questionnaire given to approximately 77 organizations throughout Oregon will be used. This study (the Concord Study) was conducted in 1974 by staff members from the Institute on Aging, Portland State University, and involved an extensive interview with a staff person in organizations representing the following sectors: local government, local service agencies, senior groups, and other related organizations. The districts covered in the survey included such counties as Washington, Columbia, Clackamas, Multnomah, Lane, Wasco, Sherman, Hood River, and Clark County. The main focus of the questionnaire centered on their perception of the Area Agency on Aging in terms of conflict and coordination in their particular network. The questions used for this description involved: 1) How they see the impact of the AAA on the local service community, and the elderly; 2) what they thought the AAA is supposed to do for old people, government bodies, and local service agencies, and how that compares with what they thought the AAA is actually doing to meet their goals and objectives; and 3) the extent to which the AAA has collaborated with other pro- 
grams in terms of joint activities.

Given this relatively limited amount of data, it is important to note that the intent of using the $A A A$ as case material in this context is not to empirically test these propositions per se. Rather this is a theoretical attempt to describe the vertically-oriented organization with the hope that furture elaboration and refinement will be made in this relatively untouched area.

\section{DIRECTION AND SOURCE OF AUTHORITY}

Proposition 1. Where there are organizations founded by an individual or a small group who appoint staff, and when staff creates committees, divisions, and branches, the delegation of authority is directed downward.

Robert Hudson (1974, pp. 43-44) in his description of the developmental steps which the area agencies are required to follow through illustrates the vertical formation of the AAA. He states that,

In order to bring the area agencies into existence the state agencies are charged with 1) seeing that the state establishes planning service areas - which may or may not correspond to other substate planning jurisdictions for purposes of aging planning, 2) determining which of these areas should be designated high priority areas - that is, eligible for special funding for both planning and special services, 3) determine what type of agency or organization is to be designated as an area agency either public, private, or non-profit, and 4) making an initial planning grant to such an agency for purposes of comprehensive aging planning. 
The staff of the new agency, in turn, are charged with the development of comprehensive and coordinated programs. As is obvious from this description, the formation or the development of the area agency follows along a vertical pattern - from the federal government to the state and on down to the area level. Moreover, because this development does take on a vertical pattern, it is possible to see where the ultimate source of authority lies. The federal government has the final decision-making authority over these agencies. This final decision-making power relates to the issue of who controls the resources and who makes the stipulations as to where and how this money and authority should be used.

\section{CONTROL OF RESOURCES (Accountability)}

Proposition 2. Where the authority runs downward from the federal or state to the local level, the ultimate control of resources and the decisionmaking within the organization rests with national headquarters, i.e., they are "conditionally autonomous."

To reiterate, the vast bulk of resources (money and legitimation) flowing into the vertically-oriented organization are controlled by the parent body. This is particularly apparent in the Area Agency on Aging where the vast bulk of their financial support and their legitimation is provided to them by the federal government for their support. Given the fact that organizational decision-makers are 
typically oriented to the adequate supply of resources and that this orientation determines, within fairly restrictive limits, the nature of interactions on the service delivery level and in the performance of mandated functions, then this has important implications for the functioning of the Area Agencies on Aging.

Compared with the older amendments (the 1965, 1967, and 1969 amendments), Title III which established the area agencies is more tightly integrated administratively and is designed to have greater congruence between goals and resources (Hudson, 1974). A two-part national goal was established which federal, state, and area agencies will be working toward and which specifically focuses on 1) keeping the older American in his home environment, and 2) removing any additional economic barriers so that the older American can be economically independent. The law specifies certain target populations - the poor and minority group older persons - to receive priority attention. Special planning grants will then be appropriated to those parts of the states designated as priority areas for the development of comprehensive and coordinated networks of services (Hudson, 1974: p. 43). The area agency thus is charged with the function of eliminating gaps in services to the elderly in a given community designated as a high priority area. It is given the money and authority to perform this function. Moreover, the ability of the area agency to undertake the linkage service task at the area 
level without the need of involving other organizations serves to establish their role as unique to them. Since organizations strive to maintain their autonomy from others, then the linkage role which the federal legislation sets for the area agency enhances the ability of the agency to demonstrate that it has an identifiable role for itself which is separate from the rest of the organizations in their particular network. This role affords them the legitimacy to function in this capacity.

Recognizing that this may not be enough, that substantially increased funding alone is not sufficient to provide for the full-range of services to the elderly, the Area Agencies on Aging are also charged with the task of "pooling" untapped resources on behalf of the elderly. This function calls for a mobilizing or advocating role for the AAA to make sure that other service agencies are providing sufficient services to the aging population.

Taken together, area agencies were conceptualized as organizations established explicitly to implement a national goal strategy through a series of developmental procedural steps. Funds and authority are appropriated to the area agencies specifically to fill in service gaps, and to mobilize other resources which might be available in their more immediate setting. Consequently, area agencies become organizations established by superordinate actors on whose support they are totally dependent. Should the area agency wish to 
break away from the se constraints, it would be incumbent on them to develop support from other sources, only then would they be able to pursue activities not mandated by federal or state aging officials. Area Agencies on Aging are, thus, accountable to their parent organization - they are charged with certain stipulations on which they must follow through as a condition for the receipt of funds. Although certain choices are left open to the area agency, the federal government has spelled out, in a detailed fashion, the agency's functions. They have explicit instructions for allocating the funds which the federal legislation provides. Again, this issue has tremendous implications for the way in which these organizations interact with other organizations. Because they put a great emphasis on being accountable to the federal government, they will be less inclined to initiate, or for that matter, participate in interorganizational activities.

One of the restrictions placed on the area agency on the use of these funds is that it must not provide services itself. Rather these agencies must plan for and oversee the implementation of services by other providers. The following is a list of the kind of services as specified by this legislation:

State agencies may award funds to include as part of the area plan, support for those service programs found necessary, to assist persons, to become aware of the social services available in the area (information and referral and outreach services), 
and support for other social services needed by older persons but which no public and private agencies can or will provide. (Federal Register, 1973: p. 28050)

These restrictions place a specific emphasis on information about services which are available and the means of gaining access to them. Only when these are assured can funds be used for other purposes. As organizations which are solely dependent upon one source for its resources, they must be responsible to such demands. Beyond the service areas, remaining funds are to be used for planning, coordinating, and pooling-in untapped resources. How this is to be done is left quite open. The central purpose of this nondirect service emphasis is to bring greater resources into the noninstitutionalized older population. The anticipated consequence, moreover, of this draw-in or mobilizing function is that it will help to insure the continuation of programs until federal dollars cease (Hudson, 1974).

From this description, it becomes obvious that certain characteristics of the Area Agency on Aging strongly resemble those characteristics of the vertically-oriented organization. More specifically, the vertical pattern in its formation, the dependency on the parent organization for the vast supply of resources and with it the regulations as a condition for the receipt of funds clearly demonstrate the qualities of the $\mathrm{AAA}$ as it relates to the vertically-oriented 
organization. Based on the propositions $3-7$ as stated earlier, the anticipated behavior of the AAA will be illustrated in the forthcoming section.

\section{ANTICIPATING BEHAVIOR OF THE AREA AGENCY ON AGING}

\section{Compliance}

Proposition 3. Because the vertically-oriented organization is dependent upon a parent body for virtually all its resources and is unable to reciprocate fully it ends up using compliance to the senior's wishes.

As mentioned above, the AAA has certain mandates and stipulations as to how and where the use of funds should be put, and what sort of activities should be performed. Given their relatively weak position in terms of their providers of resources, they must comply to these mandates. Moreover, because there are two quite distinct mandates, one calling for filling in service gaps, and the other for mobilizing resources, it is interesting to note the manner in which they internalize the demands which the federal government has placed on them. As will become evident in the forthcoming dis cussion, their compliance with both poses certain constraints on the organization and their ability to reach their stated goals.

In terms of the linkage role the compliance to these guidelines is well suited to the agency's situation. Besides the explicit 
instructions for the allocation of funds, the area agency is also subject to evaluation by the parent organization. Were it determined that the agency was not functioning according to expectations set out in the original guidelines, its existence would be threatened. $\mathrm{Be}-$ cause the federal government controls the flow of funds and legitimacy (it provides the AAA their uniqueness as separate from other organizations) into the linkage portion of the guidelines, the anticipated behavior of the AAA will be to comply to the government's wishes.

The draw-in role for the AAA (mobilizing resources) is marked by different characteristics. There are no dollars attached to this role as there are the linkage mandate, and as Hudson (1974) has pointed out, there is little reason for the area agencies to want to comply to this mandate in combination with the linkage role. As mentioned previously, there is an advantage to establishing the linkage function independently of other organizations. For this to be combined with the draw-in role would negate their uniqueness provided to the $A A A$ by their linkage function. Moreover, should the AAA choose to downplay the draw-in function, they would not leave themselves as open to criticism as would be the case if it chose to downplay the linkage network function (Hudson, 1974: p. 50).

Despite this reality, there still is a national mandate for this role on the AAA. Their inability to reciprocate to the dominant or parent body places them in a position of having to demonstrate that 
they are willing to work at drawing in additional resources for the aging population (they end up complying to the senior's wishes), but knowing at the same time that they run risks in doing so. This sets clear limits on the kinds of draw-in activities performed. Histories of social grant-in-aid programs indicate that the larger goals which cooperative efforts were designed to realize frequently fall short (Hudson, 1974). The underlying factor is the priority given to organizational concerns (their internal survival as it relates to the constraints imposed on them by a central authority) as opposed to the attainment of such goals.

\section{Control of Dependency}

Proposition 4. Because the vertically-oriented organization is constrained by central authority, they will be less likely to control dependency through cooperation strategies such as cooptation or coalition formation.

As stated earlier, the AAA is constrained by central authority by the fact that the vast bulk of their funds and their legitimation is controlled by the federal government - they are totally dependent on that parent body. Should the agency choose to control this dependency through cooperation strategies, such as cooptation and coalition formation, they run certain risks. To reiterate, these risks run from minor alterations in goals to cooptation by other organizations with whom it might be dealing. Moreover, these risks are proportional to 
the disparity between the organization's strength and that of its partner, and to the resources which it would contribute. Area Agencies are weak organizations in these terms since any joint undertaking would involve too great a drain from their resources. Put another way, being that the $A A A$ is a vertically-oriented organization concerned with their own internal survival, and that their resources are central to establishing their organizational integrity, they would not willingly jeopardize them to entice another organization to join with them in pursuit of an external goal which can only serve some lesser organizational purpose. The reality of the situation, however, is that the draw-in function for the AAA would result in entering into a cooperative venture with other agencies or public bodies where "all the parties concerned must agree upon an end or a goal toward which they are working," (Hudson, 1974: p. 50) making for an ambiguous situation.

As Hudson has illustrated, organizations can minimize their involvement and vulnerability when taking part in cooperative ventures by limiting ventures (in the case of the AAA this would mean tapping marginal resources of their partners or other organizations), and defining the effort in procedural terms rather than goal terms, thereby participating in a cooperative venture which is highly goal displaced. This latter point is clearly demonstrated by the greater rationalization of the program. Great care is taken in linking 
Title III appropriations and resources presumably available in the substate planning areas to program objectives which will further the overall legislative goal. By eliminating other behavioral determinants, the "abstract-rational" model around which this program was designed, risks the ability to account for a wide variety of activity much of which takes place in the name of planning. Roland Warren states these limitations concisely:

In the abstract-rational model for planning, the substantive aspects are extraneous, rational calculation is confined to substantive aspects, tends to be organized in discreet units, and is final state oriented; the action system and the planning system do not coincide, and the tendency is toward monastic decision-making. (Warren (a), 1973: p. 59)

In the course of adapting means to reach organizational goals, the means may become ends in themselves that displace the original goal thereby serving a useful purpose in minimizing the organizational vulnerability in a cooperative venture.

\section{Legitimization of Goals}

Proposition 5. Because the vertically-oriented organization expends much energy on the legitimation of goals, they lack a concrete planning or action output - they become dominated by maintenance needs.

Given the fact that the vertically-oriented organization must be accountable to that parent body who controls its resources, they 
expend much effort legitimizing their goals. Consequently, they run the risk of becoming dominated by their internal survival as opposed to focusing on change in their external environment. With this in mind, it is anticipated that as the AAA tries to legitimize its linkage function as well as its draw-in role (one being much less riskier to comply to) in the eyes of the federal government, much energy may be expended which may affect their ability to create any change in the environment. They may not be able to work at improving the overall economic or physical conditions of the elderly.

In terms of the study by the Institute on Aging (the Concord Study), the perception of the AAA by other organizations sheds some light on this point. More specifically, their perceptions of the changes in the service community (see Table II) and the conditions of the elderly (see Table III) which were the result of the AAA illustrate the possibility that on the one hand the AAA made some changes in terms of filling in certain gaps in the community, on the other hand, they made very little difference in terms of any overall change for the elderly, especially any economic change (one of their stated goals). Put into the perspective of this analysis, this perception raises the possibility that the AAA may be exerting a tremendous amount of energy fulfilling its linkage task to satisfy its accountability to the federal government, yet in the process they may be overlooking the environmental issue at hand, namely the poor economic situation for the elderly. 
TABLE II

ORGANIZATIONAL PERCEPTIONS CONCERNING THE IMPACT OF THE AREA AGENCY ON AGING ON

THE SERVICE COMMUNITY

\begin{tabular}{l|c|c|c|c|c}
\hline & $\begin{array}{c}\text { Much } \\
\text { Better } \\
\text { Off }\end{array}$ & $\begin{array}{c}\text { Somewhat } \\
\text { Better } \\
\text { Off }\end{array}$ & $\begin{array}{c}\text { No } \\
\text { Different }\end{array}$ & $\begin{array}{c}\text { Somewhat } \\
\text { Worse } \\
\text { Off }\end{array}$ & $\begin{array}{c}\text { Much } \\
\text { Worse } \\
\text { Off }\end{array}$ \\
\hline $\begin{array}{l}\text { Filling of } \\
\text { Gaps in the } \\
\text { Local Service } \\
\text { Sector }\end{array}$ & $30 \%$ & $32 \%$ & $15 \%$ & $4 \%$ & $9 \%$ \\
\hline $\begin{array}{l}\text { Developing } \\
\text { Linkage } \\
\text { Services }\end{array}$ & $26 \%$ & $36 \%$ & $18 \%$ & $3 \%$ & $8 \%$ \\
\hline \hline
\end{tabular}

TABLE III

ORGANIZATIONAL PERCEPTIONS CONCERNING THE IMPACT OF THE AREA AGENCY ON AGING ON

THE SERVICE COMMUNITY

\begin{tabular}{l|c|c|c|c|c}
\hline & $\begin{array}{c}\text { Much } \\
\text { Better } \\
\text { Off }\end{array}$ & $\begin{array}{c}\text { Somewhat } \\
\text { Better } \\
\text { Off }\end{array}$ & $\begin{array}{c}\text { No } \\
\text { Different }\end{array}$ & $\begin{array}{c}\text { Somewhat } \\
\text { Worse } \\
\text { Off }\end{array}$ & $\begin{array}{c}\text { Much } \\
\text { Worse } \\
\text { Off }\end{array}$ \\
\hline $\begin{array}{l}\text { Income Finan- } \\
\text { cial Condition }\end{array}$ & $7 \%$ & $12 \%$ & $66 \%$ & $5 \%$ & $4 \%$ \\
\hline $\begin{array}{l}\text { Prestige in the } \\
\text { Community }\end{array}$ & $11 \%$ & $35 \%$ & $35 \%$ & $10 \%$ & $7 \%$ \\
\hline $\begin{array}{l}\text { Ability to affect } \\
\text { Political Deci- } \\
\text { sions }\end{array}$ & $14 \%$ & $30 \%$ & $35 \%$ & $5 \%$ & $10 \%$ \\
\hline \hline
\end{tabular}


Moreover, this study also illustrated some disastisfaction among these organizations which again may have some bearing on the above stated proposition. With the exception of planning for old people, there was no significance (statistically) in what these organizations thought the AAA was supposed to do for old people, government bodies, and local service agencies with what the AAA is actually doing in the area of planning, direct service and information (see Appendix A)

\section{Interactions}

Proposition 6. Because the vertically-oriented organization becomes dominated by internal concerns, they are less likely to become involved in intense interactions (i.e., joint activities) with other organizations in their functional geographic community.

In view of the advantages open to the Area Agencies on Aging in concentrating to a larger extent on funding a linkage delivery network, and their vertical-orientation, they will not be as inclined to involve themselves heavily with other actors (involvement in terms of joint programs) and even then it will be only to demonstrate their compliance with federal regulations. Efforts made in this area will tend to be incremental and goal displaced such as outlined above. Based on the continuum of interdependence as illustrated by Burton Gummer (1975), the relatively low level of interdependence 
that the AAA has with other organizations was illustrated by the responses (taken from the Concord Study as discussed above) to the following questions:

1. In the past year how many times have you collaborated with the AAA on the formulation of programs? (See Table IV)

2. In the past month how many times have you worked jointly on planning services to specific individuals? (See Table V)

\section{TABLE IV}

FREQUENCY OF COLLABORATIONS OF ORGANIZATIONS TO THE AREA AGENCY ON AGING

\begin{tabular}{l|c|c}
\hline Frequency & Number & Percent (\%) \\
\hline None & 8 & 14 \\
\hline $1-5$ & 24 & 34 \\
\hline $6-20$ & 11 & 15 \\
\hline $21-100$ & 7 & 10 \\
\hline More than 100 & 1 & 17 \\
\hline Not Applicable & 12 & 3 \\
\hline Don't Know & 2 & 8 \\
\hline No Information & 6 & 1 \\
\hline
\end{tabular}


TABLE V

FREQUENCY OF INTENSE* CONTACTS OF ORGANIZATIONS TO THE AREA AGENCY ON AGING

\begin{tabular}{c|c|c}
\hline \hline Frequency & Number & Percent (\%) \\
\hline None & 26 & 37 \\
\hline $1-5$ & 10 & 14 \\
\hline $6-20$ & 4 & 6 \\
\hline $21-100$ & 4 & 6 \\
\hline More than 100 & 2 & 3 \\
\hline Not Applicable & 15 & 21 \\
\hline Don't Know & 3 & 4 \\
\hline No Information & 7 & 10 \\
\hline
\end{tabular}

*Intense refers here as involvement with joint activities

As is evident from these results, $37 \%$ of those who responded to question 2 said, in effect, that they had no occasions to work jointly with the AAA in the past month. This points out a strong possibility that the AAA has little to do with other organizations serving the elderly in terms of any intense collaboration.

\section{Coordination}

Proposition 7. Vertically-oriented organizations, because they are less likely to become involved in joint pro- 
grams will less likely become involved in coordinated efforts with other organizations.

Based on the relationship between interdependence and coordinated efforts as demonstrated by the previous studies brought out in this theoretical discussion, one can speculate as to the ability of the AAA to become involved in coordinated efforts with other organizations. In other words, because the re is a close relationship with an organization's ability to be involved in joint programs and its ability to be involved in coordinated efforts with other organizations, then one can expect the AAA to be ineffective in reaching its stated goal, i.e., to coordinate services for the elderly. 


\section{CHAPTER V}

\section{IMPIICATIONS}

Although it was not possible to empirically test the major assumption concerning the Area Agency on Aging's effectiveness at reaching its goals within the breadth of this analysis, the use of the AAA as case material in support of the contentions with regard to the vertically-oriented organization has implications in terms of the "New Federalist's" strategy (i.e., the emphasis on the strengthening of horizontal relations through vertical means.) It points out a critical ambiguity in federal legislation. On the one hand, the amendments to the Older American Act call on the area agencies to perform one role which is essentially administrative; overseeing the development of gap-filling services. On the other hand, they are charged with a quite different task; mobilizing resources and making other planners and service providers more responsive to the needs of older persons. These two mandates, as is obvious, are quite incompatible.

The federal government has asked the area agencies to engage actively with other organizations in the area environment with the performance of the mobilizing function, when they have not been able to set the terms of their own existence in that environment because of 
their strong vertical ties. The detailed instructions regarding the development of the linkage network fosters reliance on the federal aging structure while mobilizing resources requires that attention be concentrated at the area level.

While the original rationale for the area strategy was based on the need to develop support for aging services at the substate level, the way in which the Older American Amendments are being implemented will only serve to reinforce the vertical structure. This strategy has attempted to depart from the traditional forms of federal control, yet it has not departed from the investment in the coordination process. Consequently, it is suggested in this analysis that this strategy will not be successful mainly because of its ambiguous nature - it has served to strengthen vertical ties in the community through the elaboration of planning technology and the proliferation of federal rubric through coordination while at the same time focusing on the maintenance of horizontal relations.

As was demonstrated by this analysis, the vertical pattern can be seen as a deliberate rationally planned bureaucratic structure such as illustrated by the multi-divisional decentralized structure among the major corporations as well as the development of the Area Agency on Aging. Whereas, the horizontal pattern in a community is characterized by sentiments, informality, lack of planning, and diffuse structures (Warren, 1963). Consequently, the norms, goals, and 
behavior patterns between the vertical ties and those horizontal ties in a given community do not coincide. As Roland Warren (1963) has pointed out, vertical ties are generally stronger than horizontal ties among units of any community. Moreover, the historical analysis of organizations (business, voluntary, and government-controlled relief-giving organizations) in this perspective illustrated the fact that vertical ties tend to strengthen as society becomes more complex. The typical response, however, by the federal government to this strengthening of vertical ties and the proliferation of reliefgiving organizations was to try and strengthen horizontal relations by the creation of coordinating bodies which were rationally planned bureaucratic structures. As a result, because of their own survival in terms of those who control their resources, they will not be likely to focus on the horizontal relations in the community; they will tend toward more goal displacing behavior.

Another implication with regard to this analysis has to do with inter-agency cooperation, and the ability of such an agency as the Area Agency on Aging to facilitate cooperation among agencies serving the aging population. As was demonstrated by this analysis, the independence of the vertically-oriented organization from the rest of the community and greater dependence on a system outside the community causes specific types of disagreements among the local system. Moreover, because of the strong vertical ties of the 
Area Agency on Aging, and thus the inability for this organization to get involved in any intense interaction with other organizations, it is predicted that it will not enter into a situation with other organizations where this conflict can be aired. A question can be raised, therefore, as to the Area Agency on Aging's ability to facilitate cooperation when it is unable to enter into a cooperative situation because of its internal as well as its external structure.

With this in mind, it is the hope of this analysis that future enquiry into this relatively untouched area will be made. More specifically, it is recommended that research be made which focuses on the New Federalist's strategy and its attempt to strengthen horizontal relations through vertical means. Using the variables dependency/interdependency and frequency of interactions, as was used in the context of this analysis, offers a theoretical base for such enquiry, and a point of departure for future developments in the a rea of the vertically-oriented organization. 


\section{BIBLIOGRAPHY}

Advisory Commission on Intergovernmental Relations. A Commission Report: Intergovernmental Relations in the Poverty Program, Washington, D.C.: U.S. Government Printing Office, 1966.

Aiken, Michael and Jerald Hage. "Organizational Interdependence and Intra-Organizational Structure," American Sociological Review, 1968, 33:912-29.

Aldrich, Howard. "An Organization-Environment Perspective on Cooperation and Conflict Between Organizations in the Manpower Training System," In Anant R. Negandhi (ed.), Interorganization Theory, Kent, Ohio: Kent State University Press, 1973.

Benson, J. Kenneth. "The Interorganizational Network as a Political Economy," Administrative Science Quarterly, 1975, 20:22949 .

Blau, Peter. Exchange and Power in Social Life, New York: John Wiley and Sons, 1964.

Blau, Peter and Richard Schoenherr. The Structure of Organizations, New: Basic Books, 1971.

Chandler, Alfred. Strategy_and Structure, Cambridge, Mass.: The M.I. T. Press, 1962.

Child, John. "Organizational Structure, Environment and Performance: The Role of Strategic Choice," Sociology, 1972, $6: 1-22$.

Federal Register 8, 196 (October 11, 1973).

Gouldner, Alvin. "The Norm of Reciprocity," American Sociological Review, 1960, 25:161-178. 
Gummer, Burton. "The Interorganizational Relationships of a Public Welfare Agency," Journal of Sociology and Social Welfare, $1975,3: 34-47$.

Hage, Jerald. "A Strategy for Creating Interdependent Delivery Systems to meet Complex Needs," In Anant R. Negandhi (ed), Interorganization Theory, Kent, Ohio: Kent State University Press, 1975.

Hall, Richard. Organizations: Structure and Process, Englewood Cliffs: Prenctice-Hall, 1972.

Hall, Richard and John Clark. "Problems in the Study of Interorganizational Relationships," Organization and Administrative Sciences, $1974,5: 45-60$.

Hudson, Robert. "Rational Planning and Organizational Imperitives: Prospects for Area Planning in Aging," The Annals of the American Academy of Political and Social Sciences, 1974, $415: 41-54$.

Jacobs, David. "Dependency and Vulne rability: An Exchange Approach to the Control of Organization, "Administrative Science Quarterly, 1974, 19:45-59.

Levine, Sol and Paul White. "Exchange as a Conceptual Framework for the Study of Interorganizational Relationships," Administrative Science Quarterly, 1961, 5:583-601.

Levine, Sol; Paul White; and Benjamin Paul. "Community Interorganizational Problems in Providing Medical Care and Social Services," Academy of Management Journal, 1963, 53:1183-1195.

Litwak, Eugene and Lydia Hylton. "Interorganizational Analysis: A Hypothesis on Coordinating Agencies," Administrative Science Quarterly, 1972, 6:395-420.

Litwak, Eugene and Jack Rothman. "Toward a Theory and Practice of Coordination Between Formal Organizations, "In William Rosengran and Mark Lefton (eds.), Organizations and Clients, Columbus Ohio: Charles Merrill Publishing Co., 1970. 
Mindlin, Sergio and Howard Aldrich. "Interorganizational Dependence: A Review of the Concept and a Reexamination of the Findings of the Aston Group," Administrative Science Quarterly, 1975, 20:382-392.

Perlman, Robert and Arnold Gurin. Community Organization and Social Planning, New York: John Wiley, 1972.

Piven, Francis and Richard Cloward. Regulating the Poor, New York: Vintage Books, 1971.

Pugh, D.S.: D.J. Hickson; C.R. Hinnings; and C. Turner. "The Context of Organization Structure," Administrative Science Quarterly, 1969, 14:91-104.

Rothman, Jack. Planning and Organizing for Social Change, New York: Columbia University Press, 1974.

Seider, Violet. "The Historical Origin of the American Volunteer," In William Glasser and David Sills (ed.), The Government of Associations, Chicago, Ill.: The Bedminster Press, 1966.

Sills, David. The Volunteers, Glencoe, Ill. : The Free Press, 1957.

Smith, Russel and Dorothy Zeitz. American Social Welfare Institutions, New York: John Wiley \& Sons, Inc., 1970.

Sundquist, James and David Davis. Making Federalism Work: A Study of Program Coordination at the Community Level, Washington, D. C.: The Brookings Institute, 1969.

Thompson, James. Organizations in Action, New York: McGaw-Hill, 1967.

Thompson, James and W.H McEwen. "Organizational Goals and Environment: Goal-Setting as an Interaction Process," American Sociological Review, 1958, 23:23-31.

Walker, David. "How Federalism Fares in the Mid-Seventies," The Annals of the American Academy of Political and Social Science, 1974, 416:17-31.

Warren (a), Roland. Truth, Love, and Social Change, Chicago: Rand McNally, 1973. 
Warren (b), Roland. "Comprehensive Planning and Coordination: Some Functional Aspects," Social Problems, 1973, 20: 355-364.

Warren, Roland. Community In America, Chicago: Rand McNally, 1963.

Wetle, Terrie and Lawrence Rice. "New Federalism: A Business Management Change of the Highest Magnitude," A paper prepared for the Gerontological Society Meeting, Portland, Oregon, 1974.

Yuchtman, Ephraim and Stanley Seashore. "A System Resources Approach to Organizational Effectiveness," American Sociological Review, 1967, 33:891-903. 


\section{APPENDIX}

A. Organizational responses to perceived objectives of AAA to do planning for old people in relation to accomplishment of planning objectives by the AAA.

\begin{tabular}{|c|c|c|c|c|}
\hline \multirow{2}{*}{\multicolumn{2}{|c|}{ ' }} & Response: & \multicolumn{2}{|c|}{ The AAA is doing planning } \\
\hline & & & No & Yes \\
\hline \multirow{2}{*}{ Response: } & The AAA is sup- & Yes & 16 & 25 \\
\hline & $\begin{array}{l}\text { posed to do planning } \\
\text { for old people }\end{array}$ & & 18 & 24 \\
\hline
\end{tabular}

Chi Square $=4.4625$

$$
x^{2}>3.84 *
$$

B. Organizational responses to perceived objectives of the AAA to do planning for local service agencies in relation to the accomplishment of planning objectives.

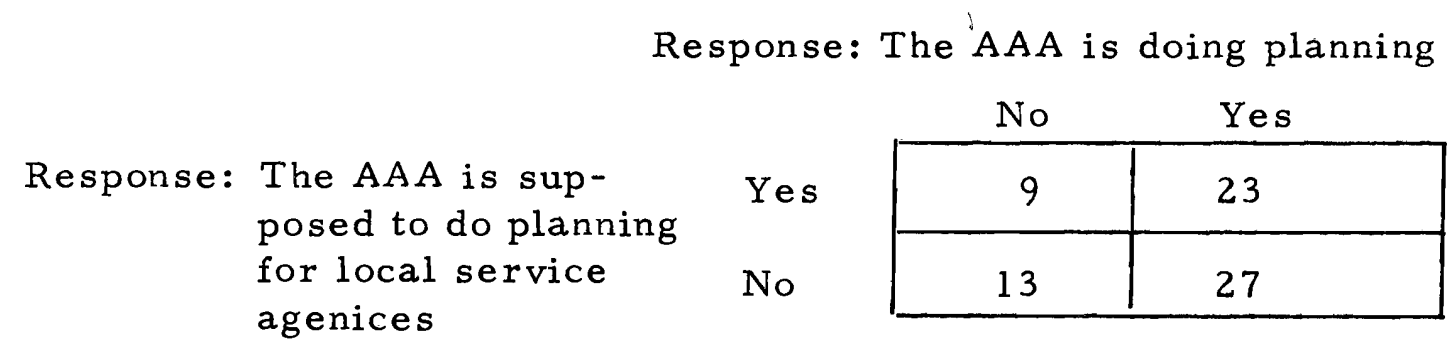

Chi Square $=.06063$

$$
x^{2}<3.84 * *
$$

*Significant at .05 level

**Not significant at .05 level 
C. Organizational response to perceived objectives of the AAA to do planning for government bodies in relation to the accomplishment of planning objectives by the AAA.

Response: The AAA is doing planning

\begin{tabular}{|c|c|c|c|c|}
\hline \multirow{3}{*}{ Response: } & & \multirow[b]{2}{*}{ Yes } & No & Yes \\
\hline & \multirow{2}{*}{$\begin{array}{l}\text { The AAA is doing } \\
\text { planning for Govern- } \\
\text { ment bodies. }\end{array}$} & & 4 & 22 \\
\hline & & & 16 & 26 \\
\hline
\end{tabular}

Chi Square $=3.98950$

$$
x^{2}>3.84 *
$$

D. Organizational responses to perceived objectives of the AAA to provide direct service for old people in relation to the accomplishment of direct service objectives by the AAA.

Response: The AAA is supposed to provide direct services to old people

Response: The AAA is providing direct service

\begin{tabular}{|c|c|c|}
\hline & No & Yes \\
\hline Yes & 17 & 11 \\
\hline No & 30 & 15 \\
\hline
\end{tabular}

Chi Square $=.26669$

$$
x^{2}<3.84 * *
$$

*Significant at .05 level

**Not significant at .05 level 
E. Organizational responses to perceived objectives of the AAA to provide direct services to local service agencies in relation to the accomplishment of direct service objectives by the AAA.

Response: The AAA is actually providing direct services

\begin{tabular}{rl|c|c|} 
Response: & \multicolumn{2}{c}{ No } & \multicolumn{2}{c}{ Yes } \\
$\begin{array}{l}\text { The AAA is sup- } \\
\text { posed to provide } \\
\text { direct service to } \\
\text { local service }\end{array}$ & Yes & 14 & 5 \\
\hline No & 34 & 19 \\
\hline
\end{tabular}
local service agencies.

Chi Square $=.57200$

$x^{2}<3.84 * *$

F. Organizational responses to perceived objectives of the AAA to provide direct services to government bodies in relation to the accomplishment of direct service objectives by the AAA.

Response: The AAA is providing direct services

Response: The AAA is supposed to provide direct services to government bodies

\begin{tabular}{c|c|c|}
\multicolumn{1}{c}{ No } & \multicolumn{2}{c}{ Yes } \\
\cline { 2 - 3 } Yes & 5 & 3 \\
\hline 40 & 20 \\
\hline
\end{tabular}

Chi Square $=.05475$

$$
x^{2}<3.84 * *
$$

*Significant at .05 level

**Not significant at .05 level 
G. Organizational responses to perceived objectives of the AAA to provide information to old people in relation to the accomplishment of information providing objectives by the AAA.

Response: The AAA is providing information

Response: The AAA is supposed to provide information to old people.

\begin{tabular}{|l|l|}
\hline No & Yes \\
\hline 13 & 14 \\
\hline 24 & 22 \\
\hline
\end{tabular}

Chi Square $=.11032$

$$
x^{2}<3.84 * *
$$

H. Organizational responses to perceived objectives of the AAA to provide information to local service agencies in relation to the accomplishment of information providing objectives by the AAA.

$$
\begin{gathered}
\text { Response: The AAA is providing } \\
\text { services }
\end{gathered}
$$

Response: The AAA is supposed to provide information to local service agencies.

\begin{tabular}{l|l|l|}
\multicolumn{1}{c}{ No } & \multicolumn{1}{c}{ Yes } \\
\cline { 2 - 3 } Yes & 13 & 21 \\
\cline { 2 - 3 } No & 23 & 15 \\
\hline
\end{tabular}

Chi Square $=3.57$

$$
x^{2}<3.84 * *
$$

*Significant at .05 leve1

**Not significant at . 05 level 